\title{
New Anomala Samouelle, 1819 from South-East Asia (Coleoptera: Scarabaeidae: Rutelinae)
}

\author{
Новые Anomala Samouelle, 1819 из Юго-Восточной Азии \\ (Coleoptera: Scarabaeidae: Rutelinae)
}

\author{
A.M. Prokofiev \\ А.М. Прокофьев
}

Institute for Ecology and Evolution, Russian Academy of Sciences, Leninsky prospect 33, Moscow 119071, Russia. E-mail: prokartster@gmail.com

Институт проблем экологии и эволюции РАН, Ленинский проспект 33, Москва 119071, Россия.

KEY WORDS: Rutelinae, Anomala, new taxa, South-East Asia.

КЛЮЧЕВЫЕ СЛОВА: Rutelinae, Anomala, новые таксоны, Юго-Восточная Азия.

ABSTRACT. Twelve new species and two new subspecies of the Ruteline beetle genus Anomala are described from Vietnam, Laos, China (Yunnan), Myanmar and Malaysia (Sabah)

РЕЗЮМЕ. ОПисывается 12 новых видов и 2 новых подвида хрущиков рода Anomala из Вьетнама, Лаоса, Китая (Юннань), Мьянмы и Малайзии (Сабах).

The Ruteline fauna of the Dalat (= Langbian) Plateau in southern Central Vietnam is very rich and highly endemic - not less than three-fourths of the species known from this area are distributed only here, and many of them are still not formally described. The Ruteline fauna of the adjoining coastal lowlands is similarly poorly known, as for southern Vietnam at all. This paper is devoted to the descriptions of a part of the new taxa collected during 2009-2012. In the course of preparation of a revision of the Ruteline beetles of the Dalat Plateau and adjacent coastal areas I had examined a wide set of specimens from the adjacent regions including several new species, which are included in this paper too.

All the type series from the author's reference collection will be submitted to the Zoological Museum, Moscow University (ZMMU); some of the paratypes, when numerous, will be donated to the other museums. Some of the paratypes also come from the collection of the Zoologisches Forschungsmuseum Alexander Koenig Bonn (ZFMK) and the private collections of Denis Keith (CK, Chartres, France), Andreas Reichenbach (CR, Leipzig, Germany), Kaoru Wada (CW, Tokyo, Japan), and Carsten Zorn (CZ, Gnoien, Germany).

\section{Anomala artemida Prokofiev, sp.n.}

Figs 1-9.

MATERIAL. Holotype, ơ', Vietnam, Binh Thuan Prov., $\sim 45$ km SW Phan Thiet, My Thanh vill., $11^{\circ} 05.530^{\prime} \mathrm{N}, 107^{\circ} 54.450^{\prime} \mathrm{E}$, alt. $180 \mathrm{~m}$, monsoon forest, 13-16.05.2012, on light, A.M. Prokofiev leg. (ZMMU)
Additional non-type specimen, $\sigma^{7}$, P.R. China, Yunnan, MengLa county, Jing-piao, alt. 200-350 m, 01-16.06.2012 (ZMMU).

DESCRIPTION. Male, holotype (Fig. 1). Length $13 \mathrm{~mm}$; greatest width $6.5 \mathrm{~mm}$. Elongate ovoid, moderately convex, strongly declivious from base of elytra to apices of clypeus and pygidium. Head and pronotum yellowish-testaceous with faint light-green metallic tint; two indistinct brownish spots between eyes and indistinct tripartite brownish markings on pronotum; basis of pronotum narrowly margined by black; scutellum yellow with dark metallic green margin; elytra black with a pair of rectangular yellow spots just behind scutellum and a yellow basal margin before humeral umbones; pygidium cherry-red; sterna dark metallic green with yellow pattern; uppersides of abdomen dark metallic green with yellow spots; in the rest, first two abdominal sternites yellow and the remaining ones cherry-red; legs yellow with dark markings, foretibiae dark metallic green from above, tarsi black; antennae and mouthparts reddish-brown.

Clypeus transverse, with broadly rounded front angles and weakly raised anterior margin; anterior part of front and clypeus densely and rugosely punctate, points confluent; punctures becoming sparser and slightly smaller on posterior portion of front and vertex; frontoclypeal suture complete, almost straight. Antennal club slightly longer than segments 2-6 combined; last joint of maxillary palpi elongately fusiform, with long and narrow but scarcely delimited area of microsculpture on its outer side, with tips pointed, bearing a patch of minute sensillae. Pronotum 1.8 times as broad as long. Sides of pronotum nearly parallel in basal half but strongly convergent in anterior half; front angles pointed, hind angles straight; basis completely bordered. Pronotum rather coarsely and densely punctured; interspaces between punctures on disc commensurable with diameter of points; punctures becoming slightly smaller and denser toward the sides; sides of pronotum with few long hairs. Basis of pronotum slightly shorter than the basis of elytra. Scutellum large, subtriangular, with slightly produced pointed tip, rather coarsely but somewhat irregularly punctured; punctures being slightly transversely extended. Elytra very weakly expanded caudally, approximately 1.2 times as long as broad, sulcate, punctate rows distinctly impressed and interspaces considerably and regularly convex; second interspace broader, with a secondary rib; punctures in punctate rows transversely extended; interspaces punctured with fine and sparse roundish 
points. Lateral margin of elytra narrowly expanded along almost all its length; epipleura long, sparsely setose; membranous apical border moderately narrow. Basal two-thirds of propygidium covered by elytra; propygidium punctured with moderately dense, coarse, transversely extended points. Pygidium elongate and produced posteriad, smoothly declivious, apically bulging, transversely rugopunctate to rugose at apex, with sparse short setae at apex only. Sterna tightly punctate, covered with sparse and short adpressed hairs. Prosternal and mesometasternal processes absent. Abdominal sternites finely rugopunctate at uppersides, punctures becoming separate, strongly transversely extended mesially; abdominal sternites almost bare except few very short and widely separated setae arranged into submedial row on their sides and along posterior border of the last sternite. Sides of two anterior abdominal sternites very weakly carinate.

Fore tibia bidentate, teeth sharp; inner spur orientated forward, laterad and slightly downward, attached at the level of basal tooth. Last joint of fore tarsi considerably thickened, with strong tooth on its ventral margin just before middle; inner fore claw moderately dilated, deeply clefted, with lower lobe scarcely broader; its lower margin broadly but shallowly excavated in basal half (Fig. 2). Outer middle claw clefted, lower lobe slightly broader. Meso- and metatibia narrow. 3-6).

Parameres highly asymmetrical, of peculiar shape (Figs

\section{Female unknown.}

An additional male specimen from Yunnan differs in coloration and in the outline of the distal tips of the parameres (Figs 7-9). The tripartite dark pattern on the pronotum is very pronounced, dark metallic green; the basal half of elytra is yellow except the dark longitudinal streaks under the humeral umbones and a narrow dark sutural line; pattern on the sterna and abdomen is much less pronounced than in the holotype. The color differences can be a subject of individual variations as it is common within Anomala, but slight genitalic differ-
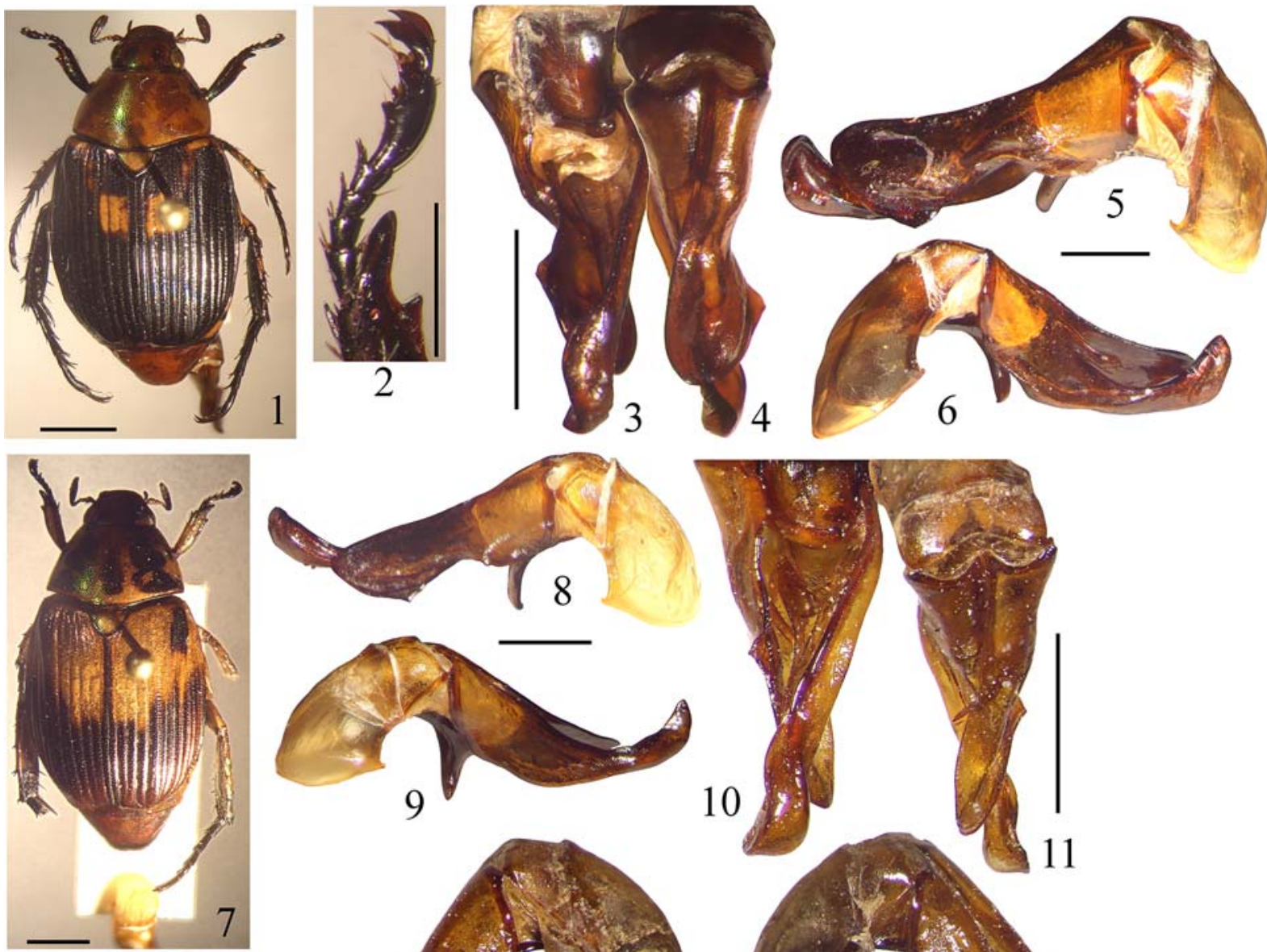

9
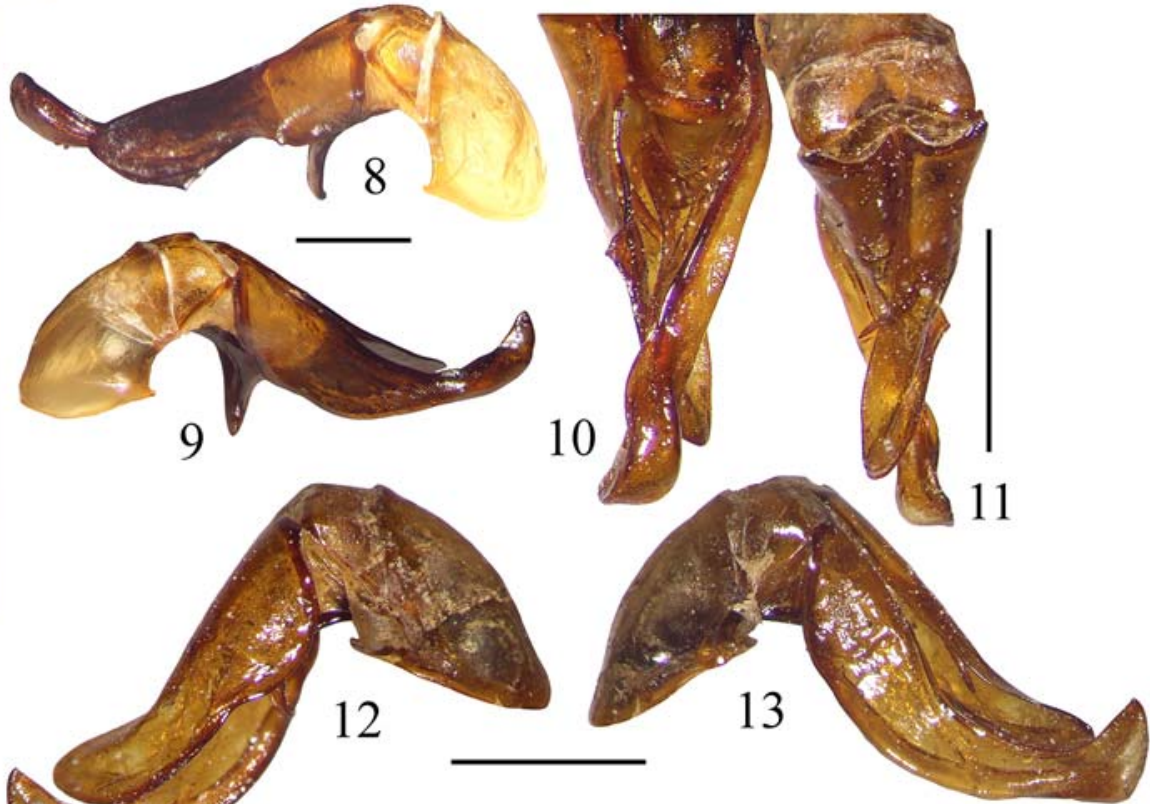

12

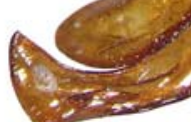

Figs 1-13. Anomala spp: 1-9-A. artemida sp.n.; 10-13 - A. bella Arr.; 1 - habitus; 2 - fore tarsus; 3-6, 8-13 - aedeagus; 1, 4, 7, 11 - dorsal view; 3, 10 - ventral view; 2, 5,8,12 — lateral view, left side; 6,9,13 — lateral view, right side; 1-6 - holotype; 7-9 - specimen from Yunnan. Scale bars (common for 3 and 4, 5 and 6, 8 and 9, 10 and 11, 12 and 13): 1 and $7-3 \mathrm{~mm}$, others $-1 \mathrm{~mm}$.

Рис. 1-13. Anomala spp: 1-9-A. artemida sp.n.; 10-13 - A. bella Arr; 1 - габитус; 2 - передняя лапка; 3-6, 8-13 - эдеагус; 1, 4, 7, 11 - сверху; 3, 10 - снизу; 2, 5, 8, 12 - сбоку, левая сторона; 6, 9, 13 - сбоку, правая сторона; 1-6 - голотип; 7-9 экземпляр из Юньнани. Масштаб (линейка общая для 3 и 4,5 и 6,8 и 9, 10 и 11, 12 и 13 ): 1 и $7-3$ мм, прочие -1 мм. 
ences may indicate a subspecific differentiation. Specimens similar to the Yunnan specimen but not to the holotype are also known from North Thailand and Laos [Zorn, in litt.]. There are also some slight differences in sculpture: punctures on front and clypeus being not confluent, on pronotum somewhat denser, and the pygidium being regularly and roughly transversely rugose. These differences, however, may reflect an individual variation. Of course, the paucity of material delays any final conclusions.

ETYMOLOGY. This species is named after the ancient Greek goddess of forest and hunting; the species epithet is noun in apposition.

DIFFERENTIAL DIAGNOSIS. Within a number of South-East Asian species having a similarly complicated aedeagus and a boat-shaped body the new species is most closely allied to A. bella Arrow, 1917 from North India, Myanmar and North Thailand, but the shape of the parameres is somewhat different and the distal tip of the basal plate is much longer in the new species (compare Figs 3-6, 8-9 and 10-13). In addition, $A$. bella has the elytra usually (but not always) almost fully testaceous (vs. predominantly or almost fully black in the new species) and the pronotum is somewhat more evenly punctured.

\section{Anomala bidoupensis Prokofiev, sp.n. Figs 14-17.}

MATERIAL. Holotype, $\sigma^{7}$, Vietnam, Lam Dong prov., between Hon Giao and Giang Ly, $12^{\circ} 10.94^{\prime} \mathrm{N}, 108^{\circ} 41.47^{\prime} \mathrm{E}$, alt. $1500 \mathrm{~m}$, on light, 30-31.05.2012, leg. A.M. Prokofiev (ZMMU).

Paratypes, $30^{7} O^{2}$, 3 우, collected with the holotype; 2 우, Hon Giao Pass, $12^{\circ} 10^{\prime} 58^{\prime \prime}$ N, $108^{\circ} 42^{\prime} 50^{\prime \prime}$ E, alt. 1625 m, 13.05.2009, on light; $30^{7} \sigma^{7}$, the same data, but $19-24.04 .2010 ; 1$, between Dalat and Din K'No, $12^{\circ} 06.215^{\prime} \mathrm{N}, 108^{\circ} 22.060^{\prime} \mathrm{E}$, alt. $1686 \mathrm{~m}$, on light, 27-29.05.2012; all leg. A.M. Prokofiev (ZMMU).

DESCRIPTION. Male, holotype. Length $16 \mathrm{~mm}$; greatest width $8.5 \mathrm{~mm}$. Elongate ovoid, moderately convex. Greenish-brown, with dark-green metallic luster; legs with cupreous luster; pilosity pale.

Clypeus transverse, with front angles broadly rounded and outer margin strongly raised, tightly rugopunctate anteriorly; posterior half of clypeus and anterior half of frons coarsely punctate to rugopunctate; punctures in posterior half of frons and on vertex becoming sparser and posteriad smaller; frontoclypeal suture complete, almost straight. Head glabrous, except a row of few long setae along the inner margin of eye. Antennal club equals segments 2-6 combined; last joint of maxillary palpi elongately fusiform, with a weakly developed field of microsculpture on its outer surface and with a patch of minute sensillae at tip. Pronotum 1.5 times as broad as long, broadest at base, with sides almost parallel in basal half, further distinctly convergent anteriad; front angles pointed, hind angles straight, basis unbordered. Pronotum coarsely and densely punctured, with spaces between punctures being much smaller than the diameter of points to almost ridge-like; punctures becoming somewhat smaller and denser (to almost rugopunctate) toward the anterior margin and the sides; punctures setigerous, setae minute, except few long hairs on the disc and along the side margins. Scutellum triangular, coarsely punctuate; punctures setigerous; setae minute, except few long hairs. Elytra weakly broadened posteriad, 1.2 times as long as broad; punctate rows strongly impressed, scratch-like, with individual punctures indiscernible; interspaces strongly convex, riblike, each between the suture and the humeral umbones being

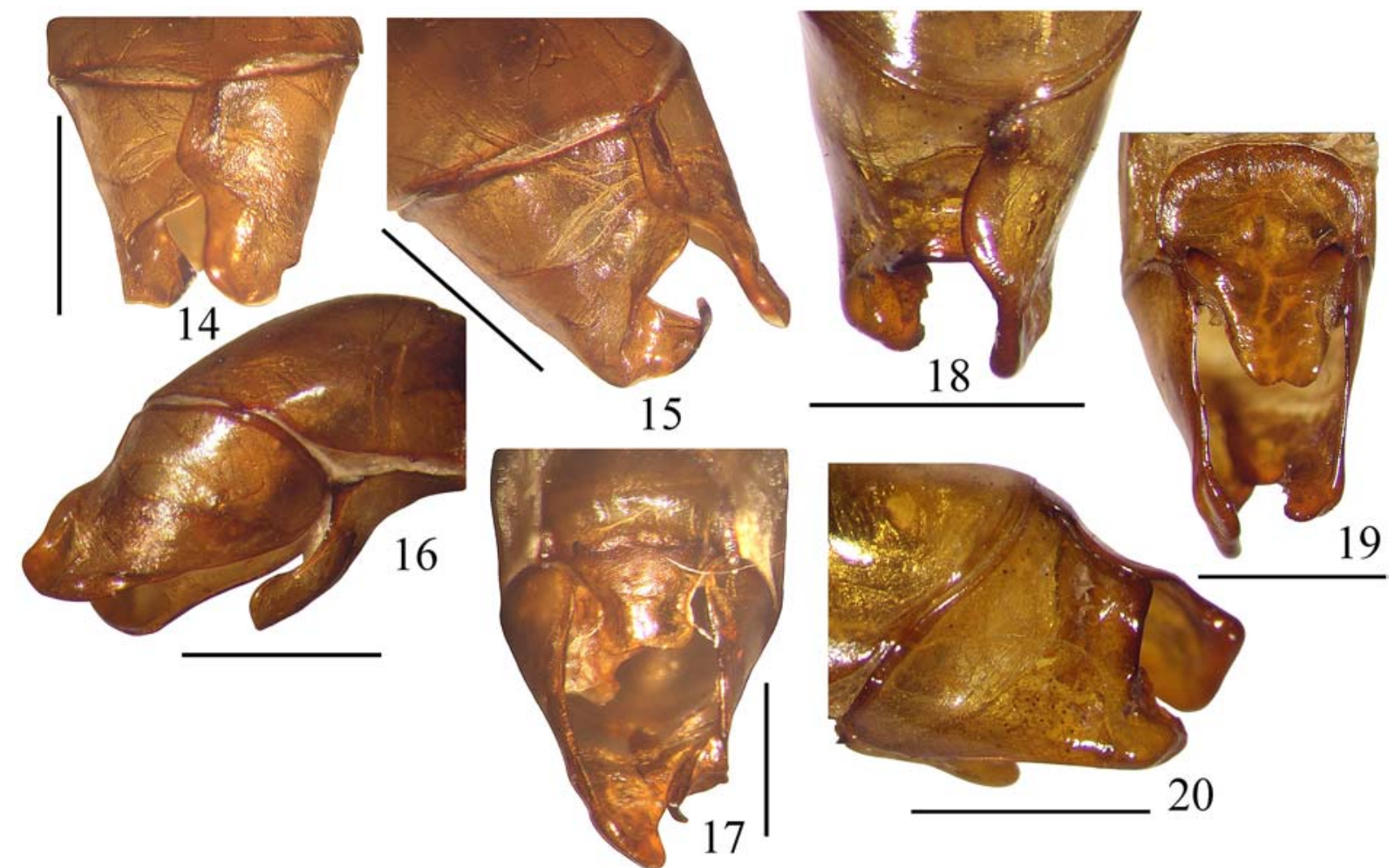

Figs 14-20. Anomala spp, aedeagus: 14-17 - A. bidoupensis sp.n., holotype; 18-20 - A. amychodes Ohs., syntype, Haut-Tonkin: Lao-Kai, R. de Salvaza; 14, 18 - dorsal view; 15, 20 - dorsolateral view; 16 - lateral view; 17, 19 - ventral view. Scale bar - $1 \mathrm{~mm}$. Рис. 14-20. Anomala spp, эдеагус: 14-17 - A. bidoupensis sp.n., голотип; 18-20 - A. amychodes Ohs., синтип, верхний Тонкин: Лаокай, Р. ди'Сальваза; 14, 18 - сверху; 15, 20 - сверху и сбоку; 16 - сбоку; 17, 19 - снизу. Масштаб: 1 мм. 
of equal width; interspaces densely and regularly punctate, punctures setigerous, setae short but well-discernible by low magnification. Epipleura long, reaching toward the apex, with a row of long and rather dense setae along all their length; membranous apical border moderately broad. Propygidium completely covered by elytra; pygidium moderately convex, coarsely transversely rugose, pilose; setae short and adpressed, except sparse long hairs at apex. Sterna densely punctured, punctures setigerous, hairs moderately long; disc of metasternum with sparse minute punctures bearing the hardly visible setae laterally, bare and smooth centrally, slightly impressed and with longitudinal furrow. Prosternal and mesometasternal processes absent. Abdominal sternites rather sparsely punctate medially, becoming rugopunctate laterally; each but last sternite possessing a complete transverse medial row of moderately long and sparse adpressed setae, uppersides densely covering by short adpressed hairs; last abdominal sternite with a row of long setae along posterior margin and with sparse minute setae on its whole surface. Sides of abdominal sternites sharply carinate, carinae on anteriormost three sternites reflexed upward.

Fore tibia bidentate, teeth sharp; inner spur orientated forward and laterad, attached slightly behind the level of basal tooth. Last joint of fore tarsi dilated distally, with ventral margin indented at middle; inner claw not very broad, deeply clefted, with lower lobe approximately 1.5 times broader than upper one, it ventral margin deeply excavated at base. Outer middle claw deeply clefted. Hind tarsi longer than metatibia.

Aedeagus is depicted on Figs 14-17.

Female. Length $16 \mathrm{~mm}$, greatest width $8 \mathrm{~mm}$. Teeth of protibiae blunter, distal tooth much longer than in the male. Last joint of fore tarsi less dilated, with ventral margin bearing hardly discernible point at middle; inner claw less dilated than in the male, its ventral margin not excavated at base.

Variations. Length $13.5-16.0 \mathrm{~mm}$, usually $15.0-16.0$ $\mathrm{mm}$; greatest width $6.5-9.0 \mathrm{~mm}$, usually $8.0-8.5 \mathrm{~mm}$ (both sexes). Green tint, metallic luster, density of punctation and length of setae on the dorsal surface are somewhat varied from specimen to specimen; frons and vertex sometimes uniformly densely and coarsely punctured. Genitalia are very constant in shape.

ETYMOLOGY. This species is named after Bi Doup Nui Ba National Park and Mt. Bi Doup in Dalat (= Langbian) Plateau, Vietnam.

DIFFERENTIAL DIAGNOSIS. Closely allied to A. amychodes Ohaus, 1914, but differs in the pilosity on the dorsal surface being much longer, having the same appearance as in the members of the hirsutula-group [see Paulian, 1959; Lin, 1996a] (vs. only minute, often hardly traceable setae on the dorsal surface in $A$. amychodes). The shape of the male genitalia is very distinctive (compare Figs $14-17$ and 18-20), especially in the general outline of the parameres and in the presence of the distal hook-like process on the right paramere in the new species.

REMARKS. Ohaus [1914] mixed apparently more than one species under the name $A$. amychodes; however, the aedeagus of the type specimen from Lao-Kai figured herein (Figs 18-20) fully corresponds with the original drawing of aedeagus in Ohaus [1914: Fig. 11]. For the time being, the species figured by Ohaus [1914: Fig. 11] is considered to be the "true" A. amychodes. A designation of the lectotype of A. amychodes is needed in the future to solve this taxonomical problem. Though there is a complex of the several, mostly undescribed, closely related species around $A$. amychodes [Zorn, in litt.], the new species can be easily recognized within this complex by an extremely long pilosity on its dorsal surface and by the shape of the male genitalia, particularly in the presence of the distal hook-like process of the right paramere but absence of a keel-like projection at the base of the latter. A. bidoupensis appears to be an endemic species of the Dalat Plateau, while the other taxa are known are known from North Indochina, South China and Cambodia. A. amychodes and its close relatives appear to be a morphological intermediate link between the "aulax" [fide Prokofiev, 2013] and "hirsutula" [fide Lin, 1996a] species groups of Anomala.

\section{Anomala chloropus condorensis Prokofiev, ssp.n.} Figs 21-27.

MATERIAL. Holotype, $\sigma^{7}$, Vietnam, Con Dao Island, Bai Dam Trau, $08^{\circ} 43^{\prime} 45^{\prime \prime} \mathrm{N}, 106^{\circ} 37^{\prime} 25^{\prime \prime} \mathrm{E}$, alt. 5-13 m, on light, 20 22.06.2012, leg. A.M. Prokofiev (ZMMU).

Paratypes, $20^{\top} \sigma^{\top}$, 4 우으, collected with the holotype (ZMMU).

DESCRIPTION. Characters identical to those described for the nominotypical subspecies [Arrow, 1917: 229] except the coloration darker (Fig. 21), the dorsal punctation larger and the aedeagus (Figs 24-26) somewhat different.

ETYMOLOGY. This subspecies is named after PouloCondore, the old name of Con Dao Island.

DIFFERENTIAL DIAGNOSIS. Differs from the nominotypical subspecies in the following traits: (1) size smaller (11.5-13.0 mm vs. $14.5-16.0 \mathrm{~mm})$; (2) dorsal coloration brownish-green with tibiae and tarsi brown with dark metallic-green luster (vs. apple-green with tibiae and tarsi deep metallic-green); (3) punctation of pronotum, scutellum and elytra somewhat larger with punctures in punctate rows of elytra almost the same in size as punctures in interspaces, punctures on elytral disc transversely extended (vs. punctation fine, little more stronger on elytra, with rather larger punctures in punctate rows); (4) anterior margin of basal plate of aedeagus with large U-shaped concavity (vs. smooth $\mathrm{V}$-shaped incision) and with tuber-like triangular projection stronger than in the nominotypical subspecies [see Arrow, 1917: Pl. II, Fig. 6]. In the rest, all the characters are identical with those described by Arrow [1917] and Chandra \& Gupta [2012] for the nominotypical subspecies.

REMARKS. The Ruteline fauna of Con Dao Island is extremely poor and includes three species of Anomala only: A. cupripes (Hope, 1839), A. densa Arrow, 1917, and the newly described form. A. densa appears to be a non-indigenous species, which is rarely collected in the rural habitats around Con Dao Town only. The population of A. cupripes from Con Dao Island differs from the mainland populations in coloration - the copper-red color on the underside and legs is replaced by green in a various degree at about $70 \%$ of the collected specimens. But this feature is not unique for the Con Dao population - within several dozens specimens of A. cupripes collected on Phu Quoc Island all possess the uniformly green coloration of the underside and legs. There are no any structural differences between these color morphs and the genitalia are identical, including the shape of the expanded inner sac of the aedeagus. The uniformly green specimens of $A$. cupripes appear to represent a color morph characteristic for the islands off southern Vietnam.

A. c. condorensis represents an island race of A. chloropus, which differs slightly but evidently from the nominative form. A. chloropus was described from the Karen Hills (Myanmar) [Arrow, 1917] and subsequently was reported from Arunachal-Pradesh (India) only [Chandra, Gupta, 2012], but is known in collections from Thailand also and apparently is widely distributed in South-East Asia [Zorn, in litt.]; however, it is still not documented for the mainland Vietnam. 

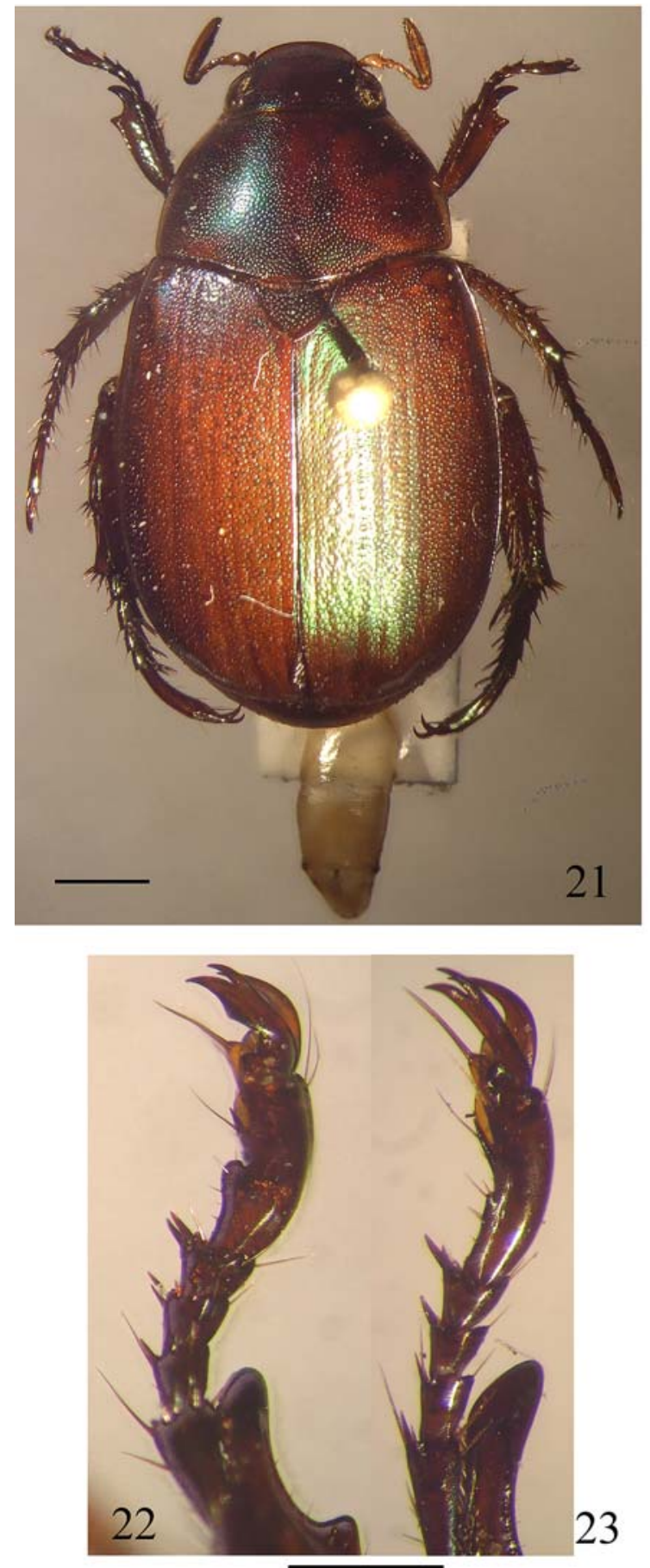

Anomala czorni Prokofiev, sp.n.

Figs 28-34.

MATERIAL. Holotype, $0^{7}$, Vietnam, Binh Thuan prov., $\sim 30$ $\mathrm{km}$ SW Phan Thiet, Ca Pet - Song Mong, $11^{\circ} 01.156^{\prime} \mathrm{N}, 107^{\circ} 52.218$ E, alt. $100 \mathrm{~m}, 11-12.05 .2012$, on light, A.M. Prokofiev leg. (ZMMU).

Paratypes, $20^{7} 0^{7}, 1$, collected with the holotype (ZMMU).

DESCRIPTION. Male, holotype (Fig. 28). Length 12.0 $\mathrm{mm}$; greatest width $6 \mathrm{~mm}$. Elongate ovoid, moderately convex, shining. Reddish-testaceous, with head cherry-red, broad dark-brown to black band along the sides of scutellum and the suture of elytra, forming an Y-shaped mark; tarsi and distal
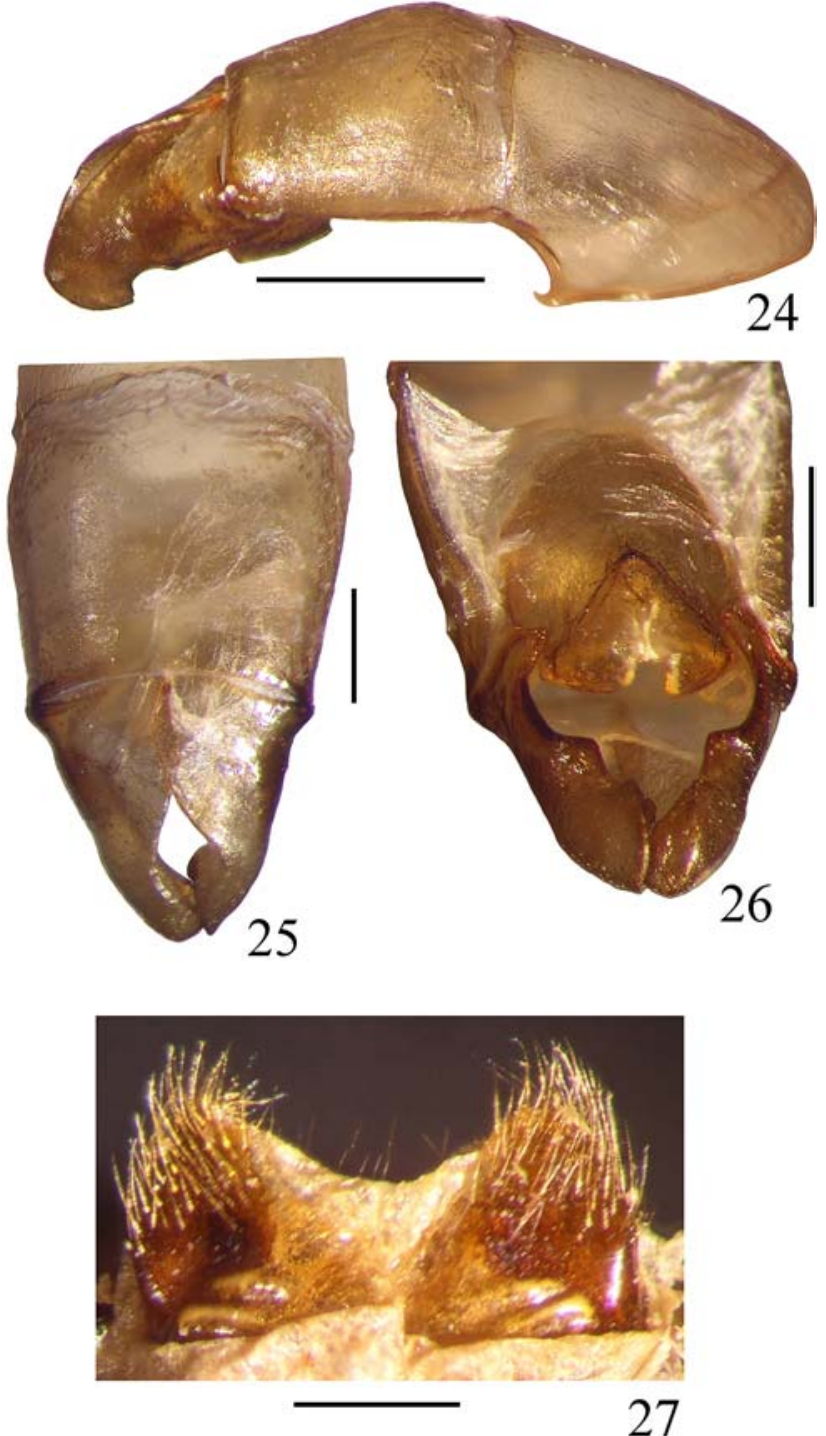

Figs 21-27. Anomala chloropus condorensis ssp.n.: 21 habitus; $22-23$ - fore tarsus; $24-26$ - aedeagus; 27 - vaginal styli; 21,25 - dorsal view; $22-24$ - lateral view, 26 - ventral view); 21-22, 24-26 - male holotype; 23,27 - female paratype. Scale bars: 21 and $24-1.5 \mathrm{~mm}, 27-0.5 \mathrm{~mm}$, others $-1 \mathrm{~mm}$.

Pис. 21-27. Anomala chloropus condorensis ssp.n.: $21-$ габитус; 22-23 - передняя лапка; 24-26 - эдеагус; 27 вагинальные стили; $21,25-$ сверху; 22-24 - сбоку, $26-$ снизу); 21-22, 24-26 - голотип, самец; 23, 27 - паратип, самка. Масштаб: 21 и $24-1,5$ мм, $27-0,5$ мм, прочие - 1 мм.

tips of all tibia more infuscated; teeth of protibia black; pilosity reddish.

Clypeus transverse, with front angles broadly rounded and outer margin strongly raised, densely and coarsely punctate; front and anterior half of vertex similarly punctate, but punctures becoming sparser in posterior half of vertex; frontoclypeal suture complete, better expressed at sides, concave. Eyes comparably large. Antennal club longer than segments 2-6 combined; last joint of maxillary palpi elongately fusiform, with ventral edge being more straightened than the dorsal one, with a weakly developed field of microgranulations on its outer surface and with a patch of minute sensillae at tip. Pronotum 
1.7 times as broad as long, broadest in basal half, where the sides are nearly parallel, but becoming strongly convergent anteriad; front angles pointed, hind angles obtuse and broadly rounded; basis completely bordered. Pronotum regularly, finely and moderately densely punctured; spaces between punctures being commensurable with diameter of points. Scutellum broadly rounded, finely punctate, with points becoming denser toward the sides. Elytra weakly broadened posteriad, 1.3 times as long as broad; punctate rows distinct, somewhat impressed, first (sutural) interspace much more convex; second interspace broad, with a patch of irregular punctures in basal quarter, these punctures arranged in a row posteriad, as coarse as in punctate rows; fourth interspace with a row of punctures, as coarse as in punctate rows; remaining interspaces bearing very sparse and minute points and microgranulations only. Epipleura long, reaching toward the apex, with a row of long and sparse setae along all their length; membranous apical border moder- ately broad. Propygidium completely covered by elytra; pygidium weakly convex; punctation rather tight and coarse in basal half and on sides, reduced apically, so disc becoming almost impunctate; pygidium bare, except a row of sparse long hairs at apex. Sterna moderately coarsely and not densely punctured, punctures setigerous, bearing short, adpressed hairs, but with few long and rather stout semierect setae bordering the posterior half of disc of metasternum; disc of metasternum bare and smooth, slightly impressed and with longitudinal furrow. Prosternal and mesometasternal processes absent. Abdominal sternites shallowly but densely punctate at uppersides, becoming almost smooth medially; each but last sternite possessing a complete transverse medial row of long sparse adpressed setae; last abdominal sternite with a row of long hairs along posterior margin. Sides of abdominal sternites non-carinate.

Fore tibia tridentate, teeth bluntly pointed, basal tooth small; inner spur long, orientated forward, laterad and slightly down-

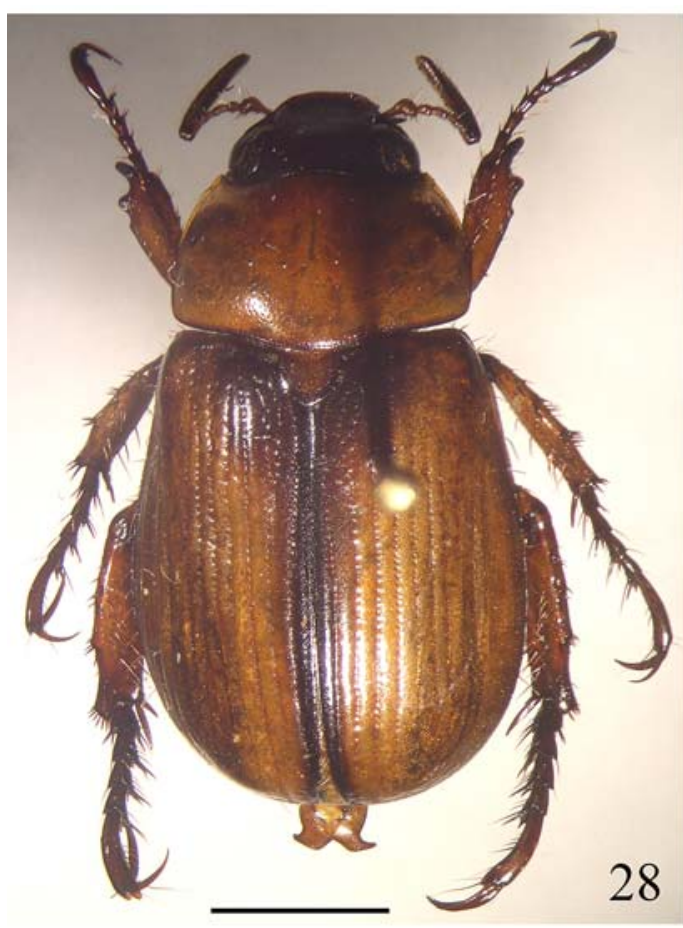

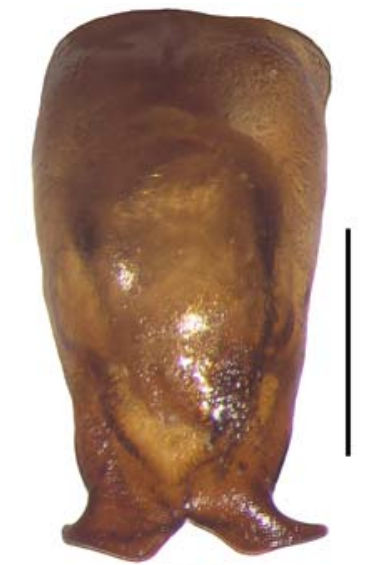
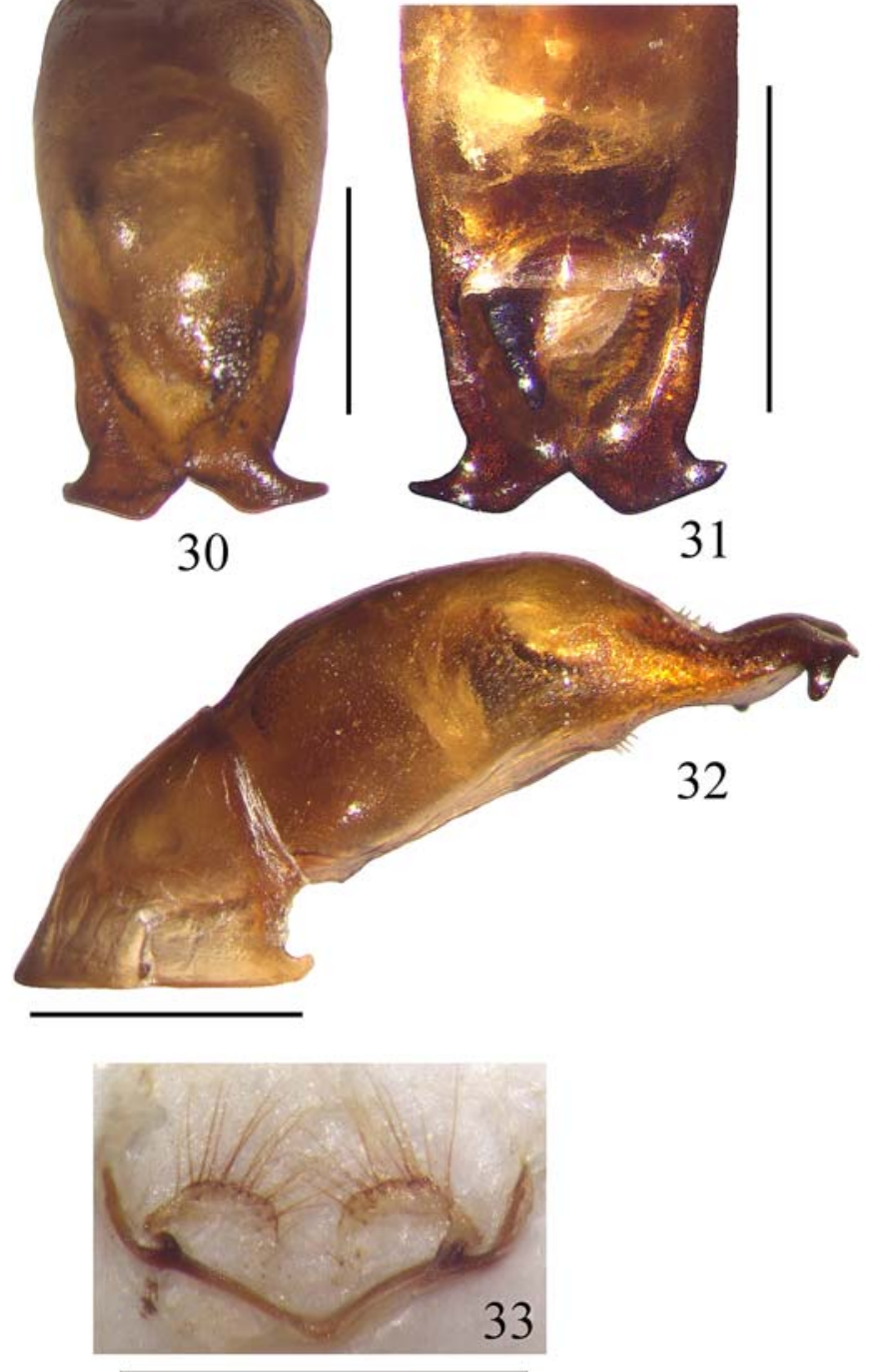

31

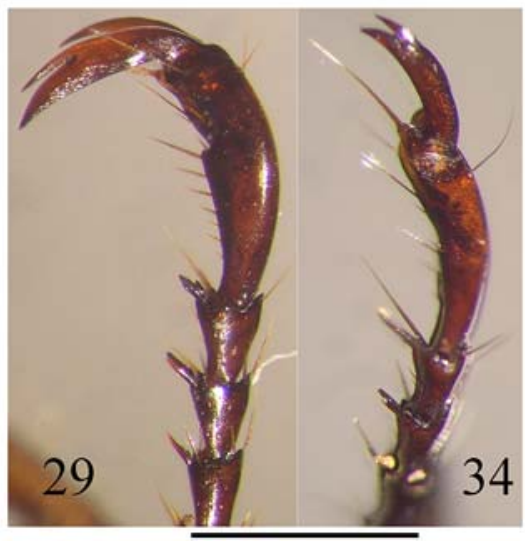

Figs 28-34. Anomala czorni sp.n.: 28 - habitus; 29, 34 - fore tarsus; 30-32 - aedeagus; 33 - spiculum gastrale; 28,30 - dorsal view, 31 - ventral view, 32 - lateral view; $28-33$ - male holotype; 34 - female paratype. Scale bars: $28-3 \mathrm{~mm}$, others - $1 \mathrm{~mm}$.

Рис. 28-34. Anomala czorni sp.n.: 28 - габитус; 29, 34 - передняя лапка; 30-32 - эдеагус; 33 - spiculum gastrale; 28,30 сверху, 31 - снизу, 29, 32, 34 - сбоку; 28-33 - голотип, самец; 34 - паратип, самка. Масштаб: 28 - 3 мм, прочие - 1 мм. 
ward, attached at the level of medial tooth. Last joint of fore tarsi dilated distally, with ventral margin indented at middle, bearing a row of rigid setae increasing in length distally; inner claw not very broad, deeply clefted, with lower lobe approximately twice broader than upper one (Fig. 29). Dorsal margin of mesotibia between the second and third (distal margin of mesotibia) transverse crests with 1-2 long stout setae. Outer middle claw entire. Hind tarsi as long as metatibia.

Parameres, as on Figs 30-32. Spiculum gastrale lacking a medial strut (Fig. 33). Inner sac of aedeagus with a single stout and flat spine, hooked apically.

Female. Length $12.5 \mathrm{~mm}$, greatest width $6.5 \mathrm{~mm}$. Pronotum twice as broad as long; elytra 1.2 times as long as broad. Protibial teeth blunter, anterior tooth longer, basal tooth less expressed than in male. Last joint of fore tarsi thin, with indentation of ventral margin indistinct; outer fore claw not dilated, with lower lobe approximately 1.5 times broader than the upper one (Fig. 34). Vaginal styli subtriangular, hairy.

Variations (males). Length $12.0-12.5 \mathrm{~mm}$, greatest width 6-6.5 mm. Pronotum 1.8-2.0 times as broad as long; elytra 1.2 times as long as broad. Apical border of elytra narrowly margined by brown or black. Apical portion of pygidium sometimes with sparse punctures.

ETYMOLOGY. This species is dedicated to Carsten Zorn (Gnoien, Germany), for his outstanding knowledge of the Oriental Rutelines.
DIFFERENTIAL DIAGNOSIS. Very similar to A. variivestis Arrow, 1917, but with black Y-shaped sutural mark on elytra broader, protibia tridentate (vs. bidentate), outer middle claw entire (vs. clefted) and with different male genitalia (see Figs 30-32 and 40-41), showing no obvious similarities with those in the related species. The species of Anomala having a pale ground coloration with or without variably developed dorsal black pattern, complete basal border of the pronotum, non-sulcate elytra with well-discernible punctate rows, simple form of the parameres and often tridentate protibia, distributed in the South-central coast and Central highland regions of Vietnam [see Nguyen \& Wada, 2006:

Fig. 9] can be differentiated by the following key.

1(7) Numerous long hairs or setae on dorsal edge between middle transverse carina and apical margin of middle tibia; inner sac of aedeagus without spines.....

2(3) Smaller (11 mm or less); elytra predominantly black, pronotum black with pale margins; protibia bidentate; aedeagus, as on Figs 79-81

A. mancipulla Prokofiev sp.n.

3(2) Larger (12 mm or more); elytra predominantly pale (except some color morphs of $A$. brevidens and A. variicolor, then pronotum pale with a pair of black spots) .................... 4

$4(5,6)$ Protibia bidentate; pronotum always testaceous; elytra with a narrow dark sutural line only; setae on elytral
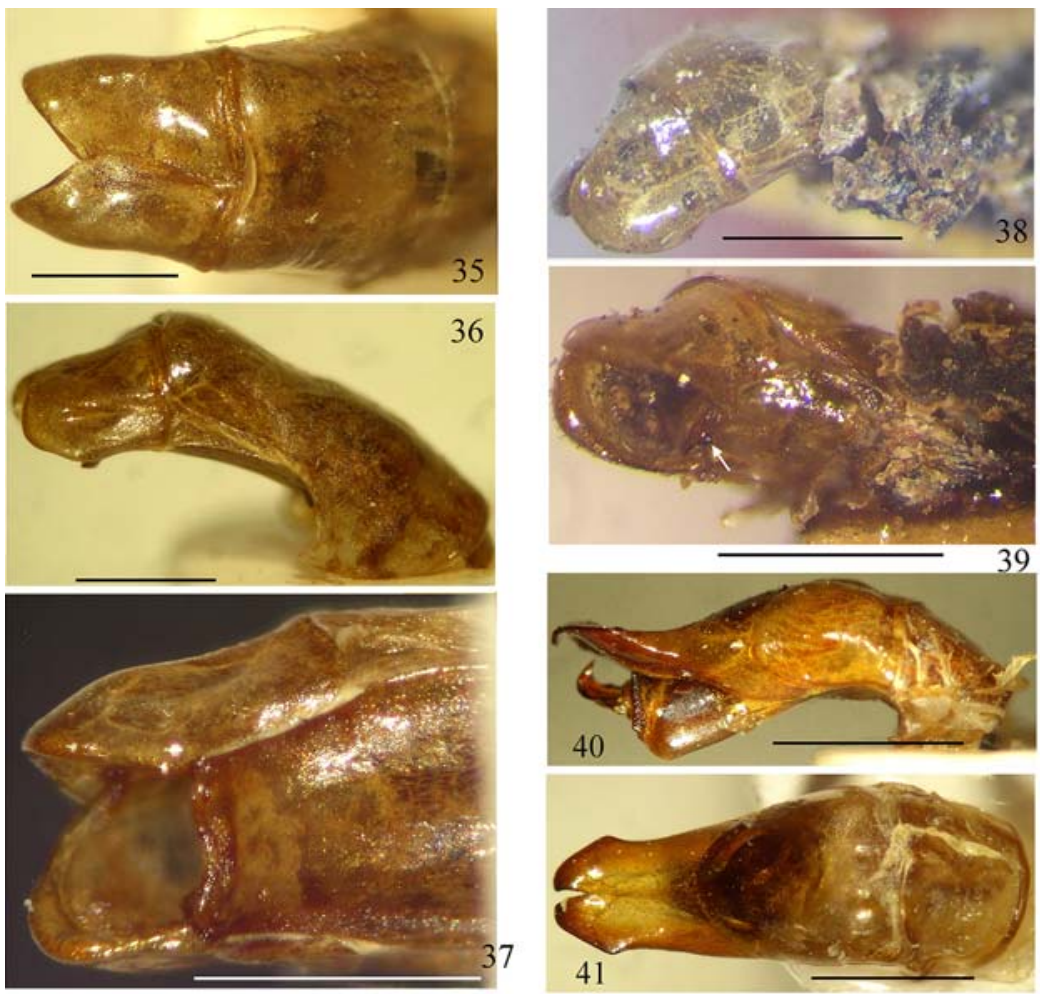

Figs 35-45. Anomala spp, aedeagus: 35-37-A. brevidens Ohs., syntype; 38, $39-A$. varicolor Gyll., specimen compared with types by Ohaus; 40, $41-$ A. variivestis Arr. specimen compared with types by Arrow; 42, $43-A$. pallida F., Cochinchina; 44, $45-A$. aspera Ohs., syntype; 35, 41, 43, 45 - dorsal view; 36, 38, 40, 42, 44 - lateral view; 37 39 - ventral view (arrow shows the reflexed tip of the basal plate). Scale bars: $40-42-1$ $\mathrm{mm}$, others - $0.5 \mathrm{~mm}$.

Рис. 35-45. Anomala spp, эдеагус: 35-37-A. brevidens Ohs., синтип; 38, 39-A. varicolor Gyll., экземпляр, сравненный Охаусом с типом; 40, 41 - A. variivestis Arr., экземпляр, сравненный Эрроу с типом; 42, 43 - A. pallida F., Кохинхина; 44, 45 - A. aspera Ohs., синтип; 35, 41, 43, 45 - сверху; 36, 38, 40, 42, 44 - сбоку; 37, 39 - снизу (стрелка указывает на отогнутую вершину базальной пластинки). Масштаб: 40-42-1 мм, прочие - 0,5 мм. 
epipleura longer than in two other species; aedeagus, as on Figs 112-114 ......... A. phanthietica Prokofiev sp.n.

$5(4,6)$ Protibia bidentate; pronotum usually with a pair of black spots; elytra with an anchor-shaped black mark in posterior half; setae on elytral epipleura shorter; aedeagus, as on Figs 35-37; distal margin of basal plate not tapered .................................. A. brevidens Ohaus, 1914 This species was known formerly from Cambodia only [Ohaus, 1914; Paulian, 1959]; I have examined specimens from Myanmar (Kachin state), Thailand (Tbanon Tong Chai), Vietnam (Binh Thuan prov.: $30 \mathrm{~km} \mathrm{SW}$ Phan Thiet) and China (Yunnan: Meng-La) also.This species was known formerly from Cambodia only [Ohaus, 1914; Paulian, 1959]; I have examined specimens from Myanmar (Kachin state), Thailand (Tbanon Tong Chai), Vietnam (Binh Thuan prov.: $30 \mathrm{~km}$ SW Phan Thiet) and China (Yunnan: Meng-La) also.

$6(4,5)$ Protibia tridentate (basal tooth sometimes minute, but always traceable); pronotum usually with a pair of black spots; elytra variably patterned, but without an anchorshaped black mark in posterior half; setae on elytral epipleura shorter; aedeagus, as on Figs 38-39; distal margin of basal plate produced in a reflexed point ....... A. variicolor (Gyllenhall, 1817)

7(1) None or few stout setae on dorsal edge between middle transverse carina and apical margin of middle tibia; inner sac of aedeagus armed with spines

8(9) Protibia bidentate, outer middle claw clefted; aedeagus, as on Figs 40, 41 ............... A. variivestis Arrow, 1917. This Burmese species is recorded for Vietnam (Binh Thuan prov., $\sim 45 \mathrm{~km}$ SW Phan Thiet, My Thanh vill.) and Laos (Khammouane prov., Pakhene) for the first time.

9(8) Protibia tridentate, outer middle claw entire ........... 10

10(11) Head with black M-shaped mark posteriorly, pale anteriorly; elytra almost parallel-sided; middle and hind tibiae distinctly thickened at middle; inner sac of aedeagus with numerous small spines and a large hooked spine; aedeagus, as on Figs 42-43 ................. A. pallida (Fabricius, 1775)

11(10) Head dark cherry-red; elytra weakly dilated caudally; inner sac of aedeagus with a large spine only ........... 12

12(13) Smaller (11.0 mm); elytra uniformly testaceous; pygidium coarsely and regularly punctate; middle and hind tibiae distinctly thickened at middle; males with ventral edge of last joint of fore tarsi clearly hooked at middle; aedeagus, as on Figs 44-45 ....................... A. aspera Ohaus, 1914 This species was described from Cambodia [Ohaus, 1914], recorded for Vietnam for the first time (Binh Thuan prov., $\sim 45$ km SW Phan Thiet, My Thanh vill.).

13(12) Larger (12.0-12.5 mm); elytra with dark Y-shaped sutural mark; pygidium weakly to almost impunctate apically; middle and hind tibiae not thickened; males with ventral edge of last joint of fore tarsi indented at middle; aedeagus, as on Figs 30-32 .... A. czorni Prokofiev sp.n.

\section{Anomala diplopsyla Prokofiev, sp.n.} Figs 46-52.

MATERIAL. Holotype, $\sigma^{7}$, P.R. China, Yunnan prov., Meng-la Co., Jing-piao, alt. 200-350 m, 1-16.06.2012 (ZMMU).

Paratypes, $2 \sigma^{7} \sigma^{\top}, 3+9$, collected with the holotype (ZMMU); 4 $\mathrm{O}^{7} \mathrm{O}^{7}$, Laos, Vientiane prov., Lao Pako env., $200 \mathrm{~m}, 55 \mathrm{~km}$ NE Vientiane, 19-22.05.2004, J. Bezdek leg. (CZ); 10, Laos, Luangphabang province, Mt. Phou Phakhao, Namtap vill., 7-11.06.2009, local collector $(\mathrm{CZ})$.

DESCRIPTION. Male, holotype (Fig. 46). Length 13.0 $\mathrm{mm}$; greatest width $7.0 \mathrm{~mm}$. Elongate ovoid, moderately convex, shining. Greenish-testaceous, with vertex and a pair of large marks on pronotum bright metallic-green, most of propygidium and basal part of pygidium metallic brownishgreen; underside and legs testaceous, but abdomen mostly reddish-brown, teeth of protibia infuscated, hind tibiae with strong green metallic luster, hind tarsi reddish-brown with green metallic luster; antennae and mouthparts reddish-testaceous; pilosity pale.

Clypeus transverse, almost semicircular with front angles undeveloped and broadly rounded, anterior margin weakly raised; clypeus coarsely rugopunctate, anterior part of front tightly punctured to almost rugopunctate, punctures becoming smaller and sparser toward the vertex; frontoclypeal suture complete, sharp, weakly concave. Antennal club slightly longer than segments 2-6 combined; last joint of maxillary palpi elongately fusiform, with a patch of minute sensillae at tip. Pronotum twice as broad as long, broadest at base; sides of pronotum almost parallel in basal two-thirds but strongly convergent anteriad; front angles pointed, hind angles almost straight, rounded; basal border interrupted before scutellum. Pronotum rather coarsely and densely punctured; interspaces between punctures on disc slightly exceeding to equal with diameters of points; punctures becoming slightly smaller and denser toward the sides; sides of pronotum with few moderately long hairs. Scutellum large, subtriangular, with obtuse tip, rather coarsely but irregularly punctured, more densely toward the outer edge. Elytra very weakly expanded caudally, approximately 1.2 times as long as broad, double-punctured with coarse punctures alternating by minute and shallow points, punctate rows indistinguishable. Epipleura long, with a row of short and sparse setae; membranous apical border moderately developed. Propygidium and pygidium finely rugopunctate. Pygidium rather convex, with a large patch of rather sparse, moderately short, adpressed hairs at each basal corner, connected along the basis of pygidium and with a row of moderately short hairs at apex, disc bare. Sterna finely punctate, covered with sparse and short adpressed hairs; disc of metasternum glabrous, weakly concave. Prosternal and mesometasternal processes absent. Abdominal sternites tightly punctate and setose at uppersides, punctures becoming separate and transversely extended mesially, much sparser toward the mid-length of abdomen; a transverse row of sparse setae just behind middle of each but last sternite; last sternite with a row of rather dense hairs along posterior margin. Sides of abdomen non-carinate.

Fore tibia bidentate; inner spur orientated forward and laterad, attached at the level of basal tooth. Last joint of fore tarsi apically thickened, with distinct tooth at mid-length of its ventral margin; inner fore claw deeply clefted, with lower lobe twice broader, its lower margin deeply excavated at base (Fig. 47). Outer middle claw deeply clefted, lower lobe 1.5 times broader. Meso- and metatibia fusiform, not thickened.

Parameres, as on Figs 48-50.

Female. Length $13.0 \mathrm{~mm}$, greatest width $7.5 \mathrm{~mm}$. Elytra slightly more expanded posteriad, 1.1 times as long as broad. Apical tooth of protibia slightly more dilated than in the male, inner spur attached just behind the level of basal tooth. Last joint of fore tarsi weakly dilated apically, its ventral margin indented at mid-length; inner fore claw less dilated, lower lobe approximately 1.5 times broader, not excavated at base (Fig. 51). Pilosity of abdomen and pygidium longer than in the male. Vaginal styli triangular, pilose (Fig. 52).

Variations. Length $13.0-14.0 \mathrm{~mm}$, greatest width 7.0 $7.5 \mathrm{~mm}$ (both sexes). Vertex sometimes testaceous in center, with a pair of green patches laterally; green patches on pronotum sometimes almost confluent; underside, pygidium and propygidium sometimes almost uniformly testaceous. Punctate rows of elytra sometimes weakly distinguishable.

ETYMOLOGY. This species is named after the Greek words "diplos" (double) and "psylos" (hairy), due to its characteristic pattern of the pilosity on the pygidium. 
DIFFERENTIAL DIAGNOSIS. This new species belongs to the sinica-group as defined by Zhang \& Lin [2008], but shows no close relationships with the other members in the shape of the male genitalia. In addition, the coloration (considerably paler from above than in the other species), especially the presence of a pair of bright metallic-green (sometimes almost confluent) marks on the pronotum and the shape of the hairy patches on the pygidium are distinctive for this species. The only species sharing a more or less similar outline of the parameres with the new species is $A$. hemiseca Zhang et Lin, 2008; however, the latter species has the tips of the parameres being much broader and much less produced apically. Furthermore, the new species differs from $A$. hemiseca in the slightly asymmetric (vs. symmetric) parameres, in the shape of the basal plate (broad, weakly concave and reflexed vs. strongly narrowed and reflexed apically in
A. hemiseca), in the finer and not umbilicate punctation of the pronotum and elytra, in the long elytral epipleura (vs. abruptlyending at elytral mid-length in A. hemiseca), and in the coloration [see Zhang \& Lin, 2008: 130, 138, Figs 13-15].

REMARKS. A large number of the undescribed species of the sinica-group is known from Indochina including the Dalat Highlands. Those listed in Paulian [1959] are largely misidentified. The sinica-group fide Paulian [1959] is highly artificial; on the other hand, some of the species having a complete basal pronotal border and therefore classified within the micansgroup by Paulian are actually belonging to the sinica-group too (i.e. A. trillesi). Some of the species recently described from China [Zhang \& Lin, 2008] are also widely distributed in Indochina (A. collotra, A. diana, A. taeniata). Anomala annamensis Benderitter ex Prokofiev, 2014 is probably conspecific with A. pyxofera Zhang et Lin, 2008; however, both of these

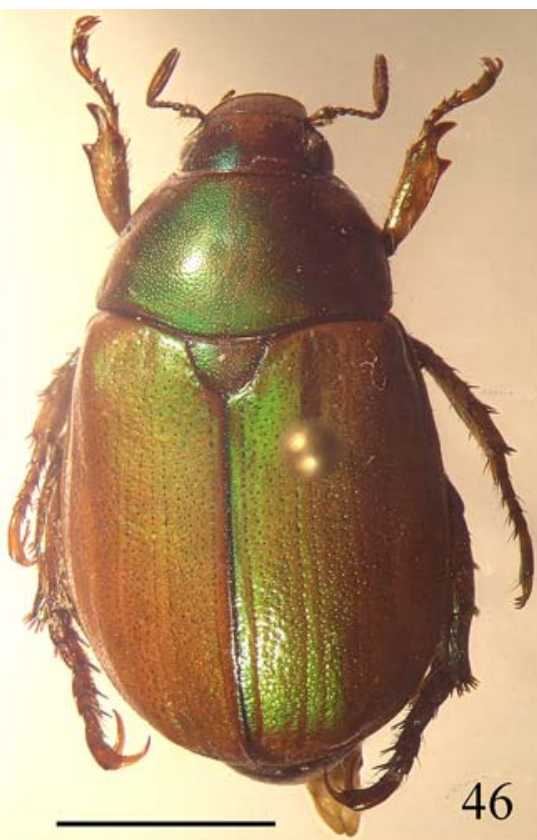

46
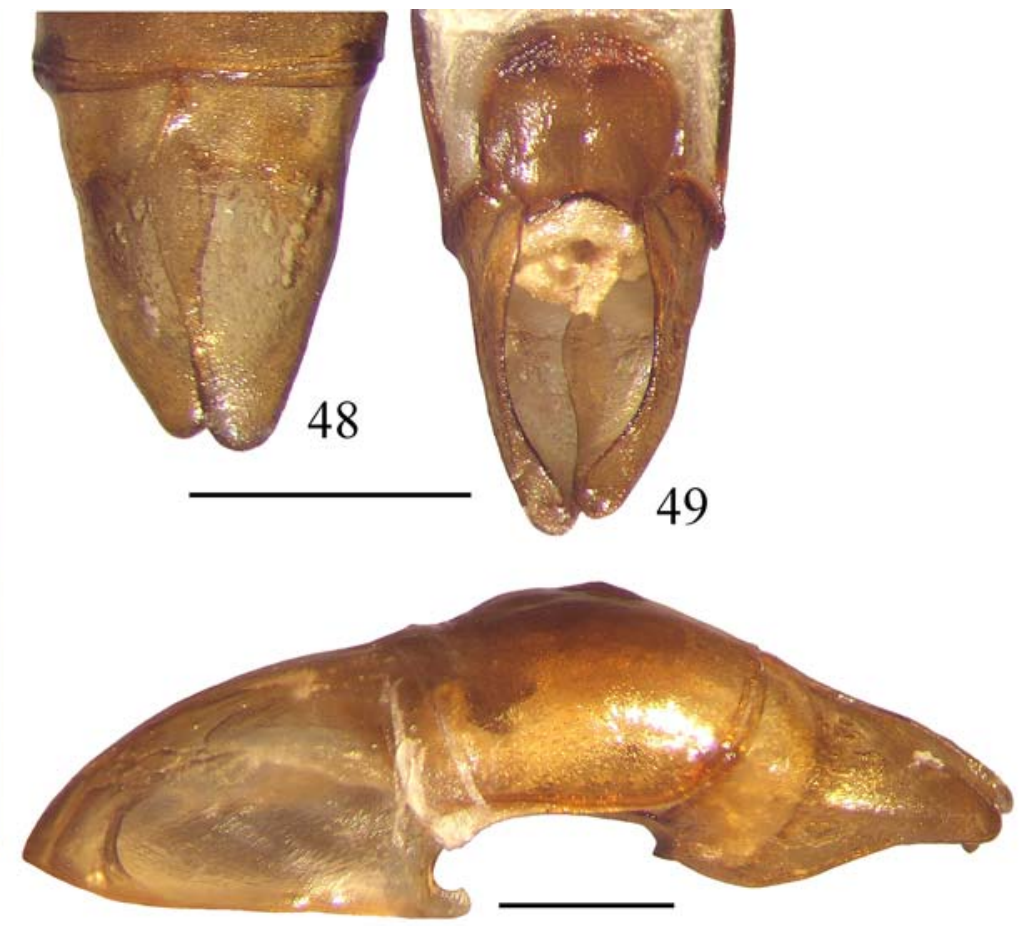

50

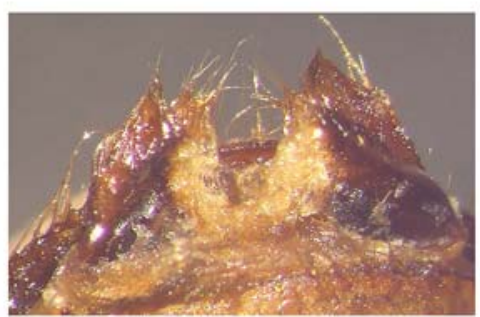

52

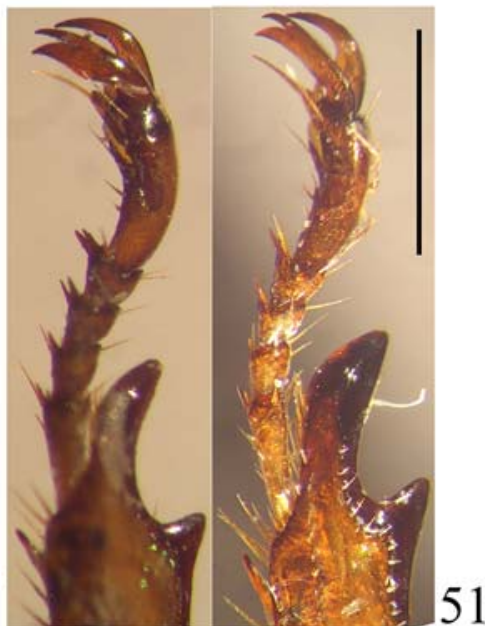

Figs 46-52. Anomala diplopsyla sp.n.: 46-50 — holotype; 51, 52 - female paratype; 46 - dorsal view; 47, 51 - fore tarsus; 48-50 aedeagus ( 48 - dorsal view; 49 - ventral view; 50 — lateral view); 52 — vaginal styli. Scale bars: $46-3 \mathrm{~mm}, 52-0.5 \mathrm{~mm}$, others - 1 $\mathrm{mm}$ (common for 47 and 51 and for 48 and 49).

Рис. 46-52. Anomala diplopsyla sp.n.: 46-50 — голотип; 51, 52 — паратип (самка); 46 - сверху; 47, 51 - передняя лапка; 4850 - эдеагус (48 - сверху; 49 - снизу; 50 - сбоку); 52 - вагинальные стили самки. Масштаб: 46 - 3 мм, 52 - 0,5 мм, прочие 1 мм (линейка общая для 47 и 51 и для 48 и 49). 
names should perhaps be synonymized with $A$. trillesi Paulian, 1959. A revision of the sinica-group in the Indochinese realm is badly needed. However, the aforementioned new species is so sharply different from the other ones that its separation is clearly undoubted already at present.

\section{Anomala eksae Prokofiev et Zorn, sp.n. * Figs 53-57.}

MATERIAL. Holotype, or, Malaysia, North Borneo, Sabah, Keningau distr., Trus Madi Mts., alt. 1160 m, 4.07.2011, leg. A. Klimenko (ZMMU).

Paratypes, $10^{7}$, 5.93, Borneo, Sabah, env. Keningau (CZ); $10^{7}$, 2 우, N. Borneo, Sabah, st. Tambunan reg., 1200 m, Trus Madi mts., 10-20.I.2006, V. Murzin leg. (CZ); 10', N. Borneo, Sabah Mamut, 29.VII.1986, local collectors legt. (AR); $10^{7}$, Keningau, N. Borneo VII.1992, B. Sakri leg. (KW); 19, Keningau, Kinabalu, Sabah, N. Borneo, 15 mile, 15.V.1988, leg. Masao Ito (KW); 10', Borneo, Sabah, Crocker Range, Keningau, V.93, Legrand leg. (DK); $10^{7}$ Borneo - Sabah, Crocker Mt. 500-1900 m, Gunong Emas, 0621.05.1995, Ivo Jeniš leg. (CZ).

DESCRIPTION. Male, holotype (Fig. 53). Length 17.0 $\mathrm{mm}$, greatest width $8.5 \mathrm{~mm}$. Conspicuously elongate, ovoid, rather flattened from above with anterior half of pronotum rapidly sloping toward the anterior margin of the clypeus; ventral profile smoothly concave between the sterna and abdomen. Dark chocolate-brown with reddish luster; scutellum and basis of pronotum with narrow black margin; legs with cupreous luster especially distinct on hind tibiae; pilosity white.

Clypeus transverse, with anterior margin straight, deep and very weakly raised, broadly rounded at sides, thus the frontal angles not traceable, tightly rusogo-punctate; anterior half of front tightly rugoso-punctate, becoming densely and coarsely punctured toward the vertex; frontoclypeal suture complete, pronounced, weakly concave at mid-length. Antennal club longer than segments 2-6 combined; last joint of maxillary palpi elongately-fusiform, with distinct elongatelyoval impressed area bearing microsculpture on its outer side and a small patch of minute sensillae at tip. Pronotum nearly trapezoidal, 1.4 times as broad as long, broadest at sides just before mid-length, very indistinctly convergent toward the base, strongly convergent toward the anterior angles. Front angles pointed, hind angles obtuse and rounded; basal margin strongly convex, with border complete but thinned before scutellum. Pronotum double-punctured, with regular and rather dense large punctures becoming slightly smaller toward the sides and minute points distributed between the large punctures; sides of pronotum with a row of few long hairs. Scutellum triangular, feebly and somewhat irregularly punctured. Elytra 1.2 times as long as broad, very weakly expanded at mid-length. Elytra moderately densely, rather finely and regularly punctate on disc; punctures becoming denser and coarser toward the sides; punctate rows hardly traceable on disc and indistinguishable on sides. Epipleura of elytra long, thickened and glabrous; membranous apical border moderately developed. Propygidium almost completely covered by elytra, densely punctate with transversely elongate points; pygidium moderately convex, tightly rugosopunctate, glabrous except few setae at basal corners and a row of long hairs at apex. Sterna densely punctate, as well as middle femora densely covered with long "fluffy" hairs. Prosternal and mesometasternal processes absent. Disc of metasternum glabrous, very finely and sparsely punctures, distinctly impressed, bearing a medial furrow. Abdominal sternites tightly rugopunctate at upper sides, punctures be- coming separate mesiad, much smaller and sparser toward the middle of each sternite. Upper sides of each but last sternite with a dense patch of hairs replacing medially by a transverse row of quite long hairs just behind a mid-length of sternite, widely interrupted in middle of all but first sternites; last sternite with a complete row of quite long hairs along its posterior margin. Sides of abdomen non-carinate.

Fore tibia bidentate, with teeth anteriorly projected, rounded at tips; basal tooth large; inner spur small, attached behind the basal tooth, orientated forward and laterad. Last joint of fore tarsi thickened apically, very weakly indented at midlength of its ventral edge; inner fore claw deeply clefted, with lower lobe twice as broad as upper lobe, its lower edge deeply excavated at base (Fig. 54). Outer middle claw deeply clefted, lower lobe 1.5 times broader. Middle tibiae thin and fusiform, with a longitudinal double carina dorsally; hind tibiae strongly thickened, much shorter than hind tarsi.

Parameres, as on Figs 55-57.

Female. Length $17.0 \mathrm{~mm}$, greatest width $10.0 \mathrm{~mm}$. Body shape much more plump, pronotum bulging at sides, its lateral margin much more curved than in males and distinctly converging towards the posterior angles; pronotum with short indistinct middle furrow. Terminal tooth of protibia tongue-shaped. Vaginal styli triangular, apically hairy. Last joint of fore tarsi less thickened than in males, its ventral margin weakly toothed; inner fore claw less dilated, lower lobe little broader than the upper one, not incised at base. Hind tibiae stouter than in males.

Variations. Length $16.0-19.0 \mathrm{~mm}$, greatest width 10.0 $10.5 \mathrm{~mm}$ (males); 17.0-19.5 and $10 \mathrm{~mm}$ (females). Color of pronotum and elytra medium red-brown to black-brown.

ETYMOLOGY. This species is dedicated to the mentor of the first author, Eugenia K. Sytchevskaya, an eminent paleontologist and ichthyologist.

DIFFERENTIAL DIAGNOSIS. Member of the cuprascens-group fide Zorn [2007] and apparently closer allied to the species around A. cuprascens (Wiedemann, 1823) because of the rather large body size and the not sulcate elytra. Anomala eksae is one of the largest species of the cuprascens-group. In contrast to several similar species, the parameres are not deeply incised (e.g. A. cuprascens, A. limatipennis Ohaus, 1916, A. kalliesi Zorn, 1998, A. diehli Zorn, 1998, A. plectrophora Ohaus, A. dissimilis Zorn, 1998) but rather simple and thus somewhat similar to those of A. sawahana Ohaus, 1926, from Sumatra (Fig. 58). However, A. eksae has a very different aedeagus with the parameres being conspiciously short (compare Figs 55-57 and 59-61) and the elytral punctation is distinctly finer.

\section{Anomala gemelloprasina Prokofiev, sp.n. Figs 62-68.}

MATERIAL. Holotype, $\sigma^{7}$, Vietnam, Khanh Hoa prov., Khanh Vinh distr., $12^{\circ} 14^{\prime} 08^{\prime \prime} \mathrm{N}, 108^{\circ} 46^{\prime} 14^{\prime \prime}$ E., alt. $750-800 \mathrm{~m}$, on light, 22-26.04.2012, leg. A.M. Prokofiev (ZMMU).

Paratypes, $1250^{7} \sigma^{7}, 132+9$, the same data as for the holotype, 14-15.05.2009, 27-29.04.2010, 22-23.04.2012, 1-6.06.2012; $310^{7} 0^{7}, 45$ 우, Khanh Hoa prov., Khanh Vinh distr., 12 $2^{\circ} 13^{\prime} 55^{\prime \prime} \mathrm{N}$, $108^{\circ} 46^{\prime} 02^{\prime \prime}$ E., alt. 877-879 m, on light, 24-26.04.2012; $1610^{7} \mathrm{O}^{7}$, 125우, Lam Dong prov., Bi Doup — Nui Ba National Park, Hong Giao to Da Nhim, alt. 1500-1700 m, on light, 13.05.2009, 1424.04.2010, 22-24.04.2012, 29-31.05.2012; all leg. A.M. Prokofiev (ZMMU). Genitalia were studied in $1020^{7} \sigma^{7}$.

NOTE: Five females from Hon Giao Pass, 22-24.04.2010, listed as paratypes of $A$. aeneoprasina [Prokofiev, 2013: 554] are included here to the type series of this new species.

* This species is described in collaboration with Carsten Zorn (Gnoien, Germany). 
DESCRIPTION. Characters identical to those described for A. aeneoprasina [Prokofiev, 2013: 554] except the denser punctation of the pronotum and elytra, always uniformly green pygidium in the females and the strikingly different aedeagus in the males.

ETYMOLOGY. This species name is derived from the Latin words "gemellus" (twin) and "prasinus" (emerald), due to significant similarity with $A$. aeneoprasina.
DIFFERENTIAL DIAGNOSIS. This new species is poorly differentiated from its sympatric sibling species $A$. aeneoprasina Prokofiev, 2013 by external characters, but has distinctive male genitalia (see Figs 66-67 and 69-70). The punctation of the pronotum is somewhat denser in the new species; the punctures on the pronotal disc are as tight as at the sides, with interspaces between them being smaller than their diameter (vs. punctures on the disc sparser than at the
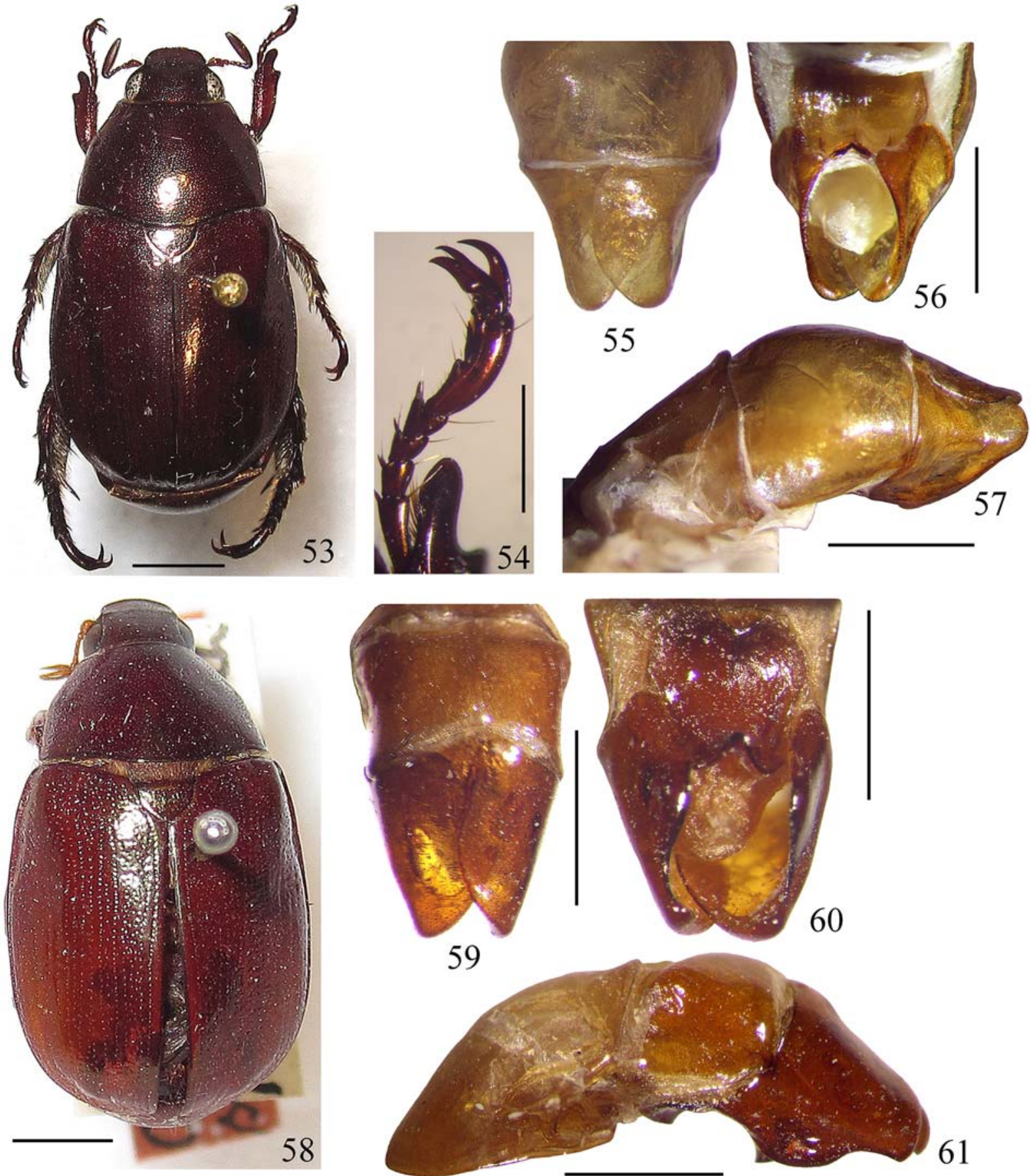

Figs 53-61. Anomala spp: 53-57 - A. eksae sp.n., holotype; 58-61 - A. sawahana Ohs., holotype; 53, 58 - dorsal view; 54 - fore tarsus; 55-57 and 59-61 - aedeagus (55, 59 - dorsal view; 56, 60 - ventral view; 57, 61 - lateral view). Scale bars: $53,58-3 \mathrm{~mm}$, others $-1 \mathrm{~mm}$.

Рис. 53-61. Anomala spp: 53-57 - A. eksae sp.n., голотип; 58-61 - A. sawahana Ohs., голотип; 53, 58 - сверху; $54-$ передняя лапка; 55-57 и 59-61 - эдеагус (55, 59 - сверху; 56, 60 - снизу; 57, 61 - сбоку). Масштаб: 53, 58 - 3 мм, прочие - 1 мм. 

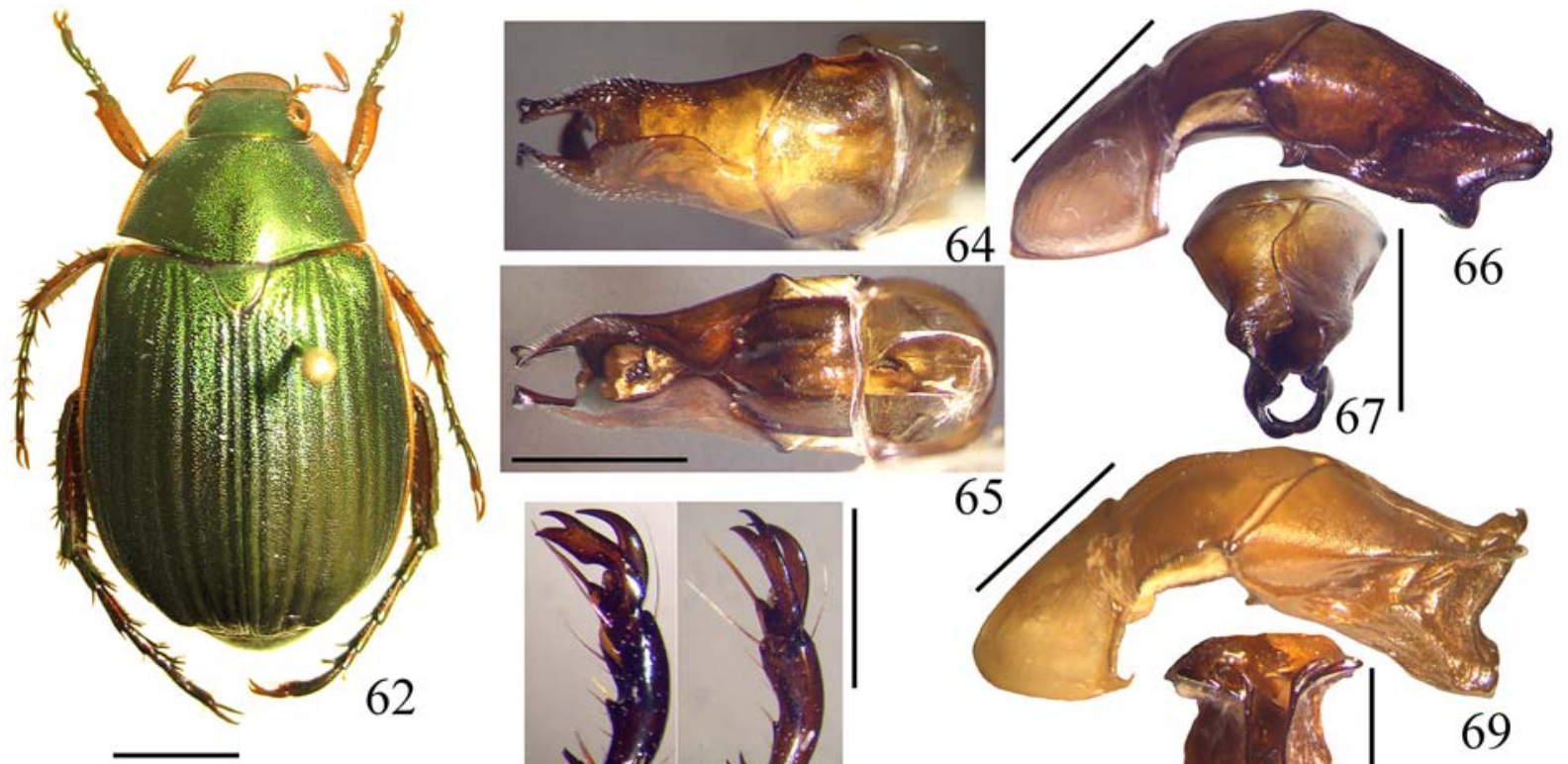

63

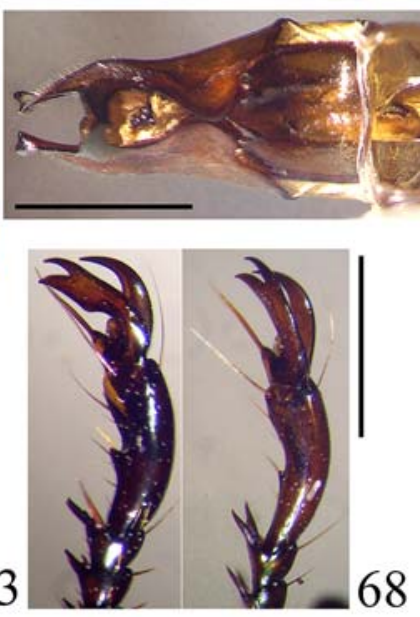

64

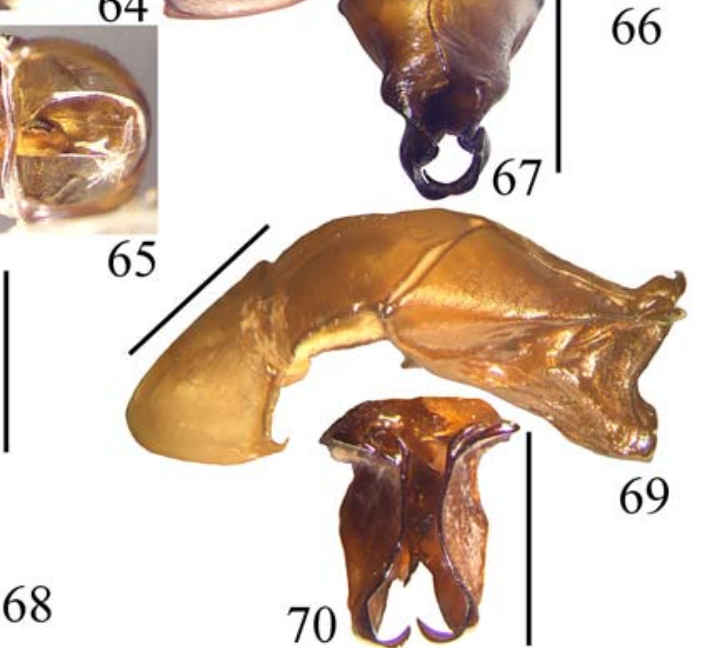

Figs 62-70. Anomala spp: 62-68 - A. gemelloprasina sp.n.; 62-67 - male holotype; 68 - female paratype; 69 , 70 - A. aeneoprasina Prok., holotype; 62 - dorsal view; 63, 68 - fore tarsus; 64-67, 69, 70 - aedeagus; 64 - dorsal view; 65 - ventral view; 66, 69 - lateral view; 67, 70 - frontal view. Scale bars (common for 63 and 68 and for 64 and 65 ): $62-3 \mathrm{~mm}$, others $-1 \mathrm{~mm}$.

Рис. 62-70. Anomala spp: 62-68 - A. gemelloprasina sp.n.; 62-67 - голотип; 68 - паратип, самка; 69, 70 - A. aeneoprasina Prok., голотип; 62 - сверху; 63, 68 - передняя лапка; 64-67, 69, 70 - эдеагус; 64 - сверху; 65 - снизу; 66, 69- сбоку; 67, 70 - спереди. Масштаб (линейка общая для 63 и 68 и для 64 и 65): 62 - 3 мм, прочие - 1 мм.

sides, with interspaces between the punctures on the disc being not smaller than their diameter in A. aeneoprasina). The punctation of the elytra is denser in the new species, both ribs and interspaces between them are punctured as densely as the second interspace (vs. second interspace is similarly densely punctured in A. aeneoprasina, but the punctures in all the other interspaces and on ribs being clearly sparser). The aforementioned differences in punctation are stable and support $100 \%$ differentiation of the species if they are directly compared. In addition, the lower lobe of the fore claw is slightly broader in the males of the new species, the inner spur is usually orientated forward and downward (vs. forward and laterad in $A$. aeneoprasina); the basis of the pygidium is usually margined by a row of rather large impressions in the new species and the females of the new species have an uniformly green pygidium (vs. yellow at apex in the females of $A$. aeneoprasina); however, all the mentioned differences are not working in $100 \%$ of the cases as some specimens of A. aeneoprasina possess the same conditions as in the new species. All other characters of A. gemelloprasina are identical to those listed in the original description of $A$. aeneoprasina [Prokofiev, 2013: 554] and are not repeated here.

\section{Anomala gypaeetus Prokofiev, sp.n.}

Figs 71-75.

MATERIAL. Holotype, $\bigcirc^{7}$, Myanmar, Kachin state, Mt. Emaw Bum, 5-22.06.2013 (ZMMU).

DESCRIPTION. Male, holotype (Fig. 71). Length $19 \mathrm{~mm}$, greatest width $10.5 \mathrm{~mm}$. Elongate ovoid, moderately convex. Grass-green, lustrous, sides of pronotum margined by yellow, apex of scutellum narrowly margined by black; pilosity pale.

Clypeus transverse, with broadly rounded, subrectangular front angles and moderately raised anterior margin, finely and tightly rusogo-punctate; frontovertex finely punctate, very densely to somewhat rugopunctate in anterior part of front, punctures becoming much sparser from posterior half of front to vertex; frontoclypeal suture complete, concave. Antennal club as long as segments 2-6 combined; last joint of maxillary palpi elongately-fusiform, with distinct elongatelyoval impressed area bearing microsculpture on its outer side. Pronotum 1.55 times as broad as long, broadest at base. Sides of pronotum very weakly convergent at basal half, sharply convergent anteriorly; front angles pointed, hind angles almost rectangular; basal margin strongly convex, with border widely interrupted before scutellum. Pronotum regularly and rather densely, but minutely and feebly punctated. Scutellum triangular, with pointed tip, feebly and sparsely punctated. Elytra 1.2 times as long as broad, very weakly expanded posteriorly. Elytra rather regularly but sparsely and minutely punctate on disc; punctures somewhat coarser than those on pronotum, becoming denser toward the sides of elytra; punctate rows being indistinguishable. Epipleura of elytra long, bearing a row of minute setae; membranous apical border moderately developed. Propygidium almost completely covered by elytra, tightly rugoso-punctate; pygidium moderately convex, with punctures being notably transversely extended, partly confluent to rugules on disc, with few moderately long hairs at apex. Sterna densely punctate, quite densely covered with moderately long decumbent hairs. Prosternal process absent. Mesometasternal process weakly developed, blunt, not protruding front of middle coxae, but mesometasternal suture obliterated between the coxae. Disc of metasternum weakly impressed, almost impunctate, bearing a medial furrow. Abdominal sternites finely transversely rugopunctate, each with a transverse row of rather sparse semi-erect setae becoming denser and arranging in few several rows on upper- 
sides; setigerous punctures being coarser and larger than the others. Sides of abdomen non-carinate.

Fore tibia with two pointed teeth; basal tooth large; inner spur orientated forward and laterad, attached at the level of basal tooth. Last joint of fore tarsi with sharply produced ventro-apical angle and with small submedial tooth; inner fore claw deeply clefted, with lower lobe much broader, its lower edge angularly excavated at base (Fig. 72). Outer middle claw incised, lower lobe twice broader. Middle and hind tibiae not broadened.
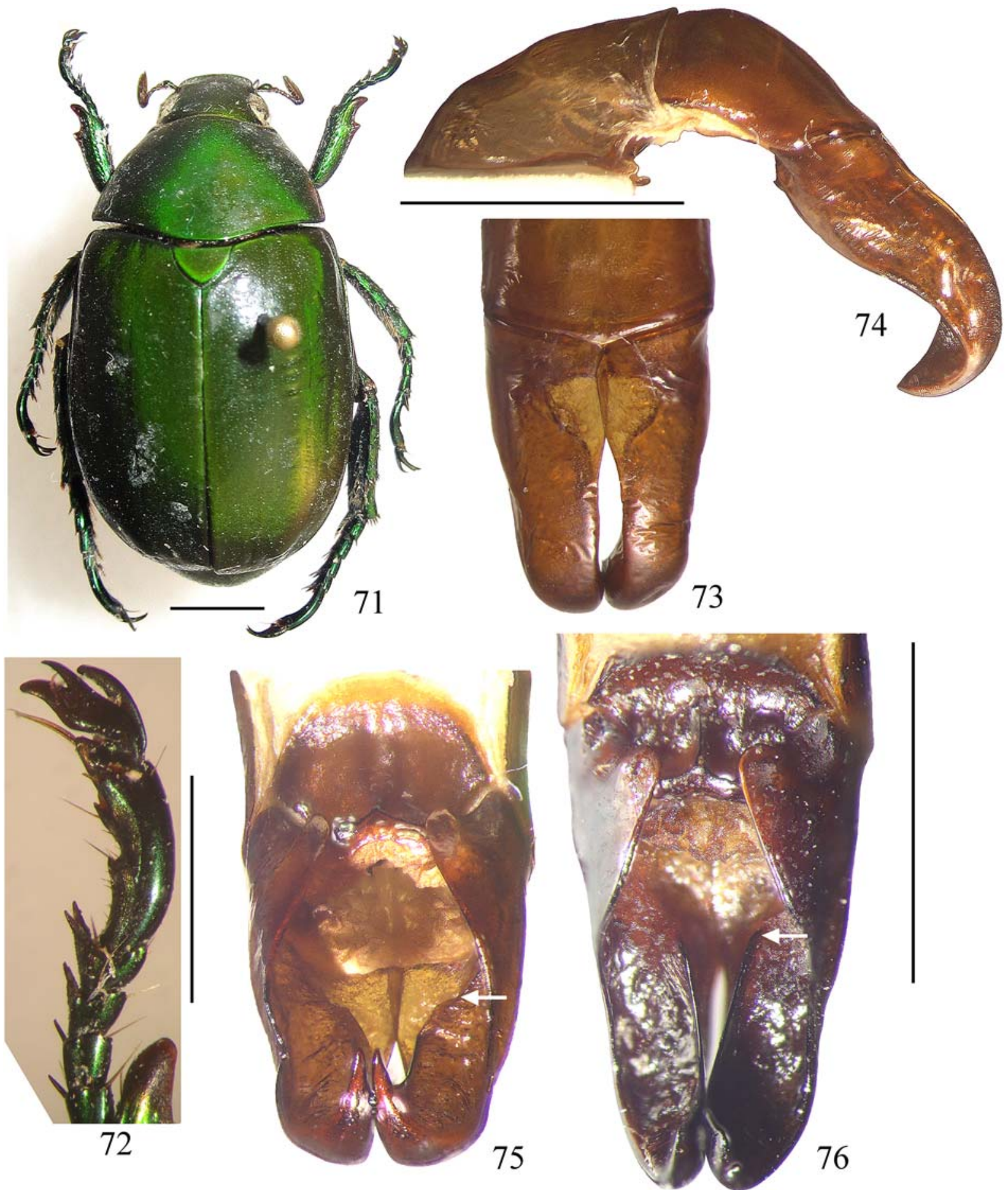

Figs 71-76. Anomala spp: 71-75-A. gypaeetus sp.n., holotype; 76 - A. haliaeetus Prok., holotype; 71 - dorsal view; 72 - fore tarsus; 73-76 - aedeagus; 73 - dorsal view; 74 - lateral view; 75 and 76 - ventral view; endings of the inner ventral ridge of the paramere arrowed. Scale bars (common for 73 and 74 and for 75 and 76): 71, 73-76 - $3 \mathrm{~mm}, 72-1 \mathrm{~mm}$.

Рис. 71-76. Anomala spp: 71-75 - A. gypaeetus sp.n., голотип; 76 - A. haliaeetus Prok., голотип; 71 - сверху; 72 - передняя лапка; 73-76 - эдеагус; 73 - сверху; 74 - сбоку; 75 и 76 - снизу; окончания внутреннего вентрального гребня парамеры показаны стрелками. Масштаб (линейка общая для 73 и 74 и для 75 и 76): 71, 73-76 - 3 мм, $72-1$ мм. 
Parameres not touching each other along the mid-line at most of their length, sharply bent downward apically, pointed at tips (Figs 73-75).

Female unknown.

ETYMOLOGY. This species is named after the kinds of the birds of prey ("gyps" — a vulture; "aëtus" — an eagle), in analogy to the closely related species A. haliaeetus, as the shape of its male aedeagus is very similar in lateral view to the bird-of-prey's bill; the species epithet is noun in apposition.

DIFFERENTIAL DIAGNOSIS. Close to A. haliaeetus Prokofiev, 2013, but differs in much finer punctation of the dorsal surface, the presence of a yellow marginal band at the

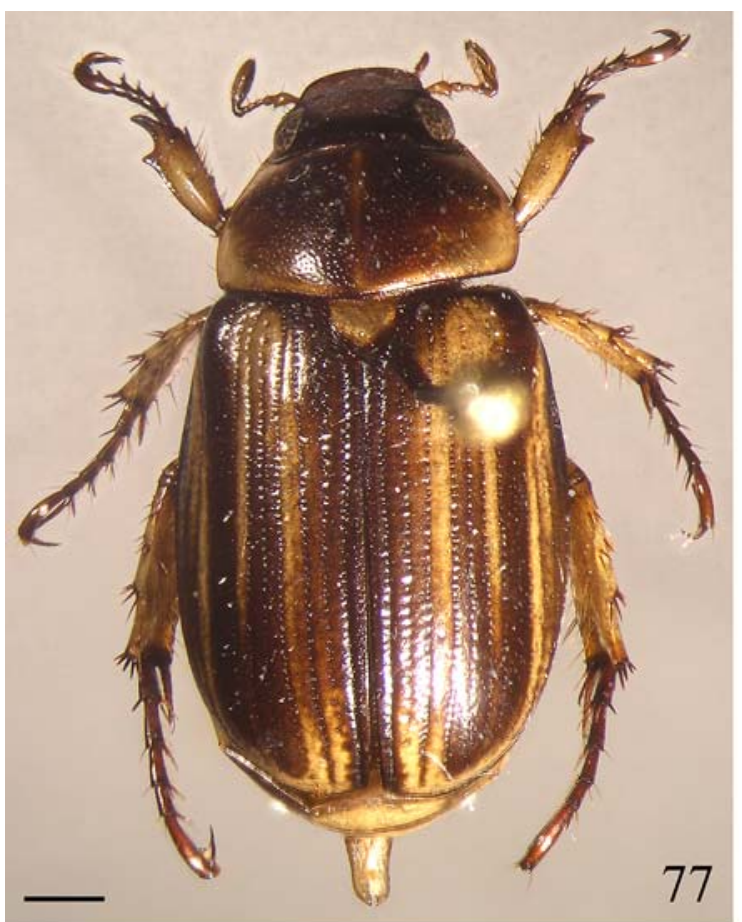

77

78

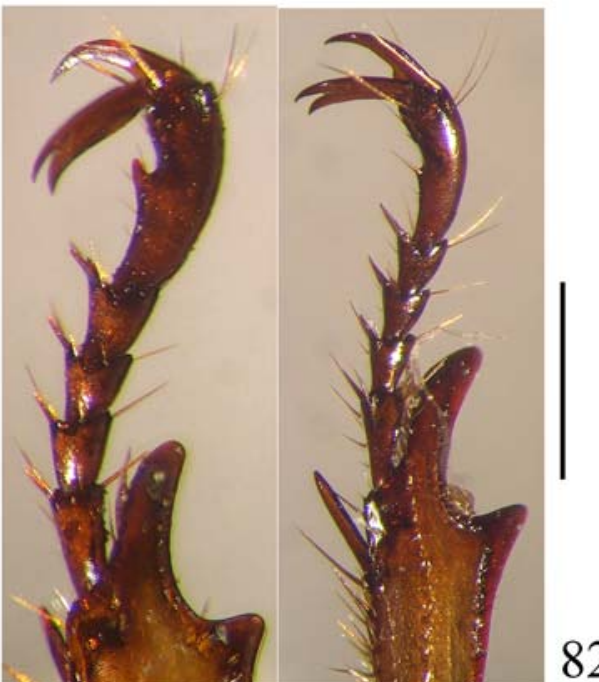

Figs 77-83. Anomala mancipulla sp.n.: 77-81 — holotype; 82, 83 - female paratype; 77 - dorsal view; 78, 82 - fore tarsus (scale bar common); 79-81 — aedeagus; 79 - dorsal view; 80 - lateral view; 81 — ventral view (scale bar common); 83 — vaginal styli. Scale bars: $77-1 \mathrm{~mm}, 78-82-0.5 \mathrm{~mm}, 83-0.25 \mathrm{~mm}$.

Рис. 77-83. Anomala mancipulla sp.n.: 77-81 - голотип; 82, 83 - паратип (самка); 77 - вид сверху; 78, 82 - передняя лапка (линейка общая); 79-81 — эдеагус; 79 - вид сверху; 80 - сбоку; 81 - снизу (линейка общая); 83 - вагинальные стили самки. Масштаб: $77-1$ мм, 78-82-0,5 мм, $83-0,25$ мм. sides of pronotum, a somewhat more gracile aedeagus, with parameres broader in dorsal view and much more widely spaced from each other in the middle, bearing much shorter and weaker inner ventral ridge (compare Figs 75 and 76).

\section{Anomala mancipulla Prokofiev, sp.n.}

Figs 77-83.

MATERIAL. Holotype, $\sigma^{7}$, Vietnam, Binh Thuan prov., $\sim 30 \mathrm{~km}$ SW Phan Thiet, Ca Pet - Song Mong, $11^{\circ} 01.156^{\prime} \mathrm{N}, 107^{\circ} 52.218^{\prime} \mathrm{E}$, alt. $100 \mathrm{~m}, 11-12.05 .2012$, on light, A.M. Prokofiev leg. (ZMMU).

Paratypes, $4 \bigcirc^{7} \sigma^{7}, 20$ 웅, collected with the holotype (ZMMU).

DESCRIPTION. Male, holotype (Fig. 77). Length 9.5 $\mathrm{mm}$; greatest width $4.2 \mathrm{~mm}$. Elongate ovoid, moderately
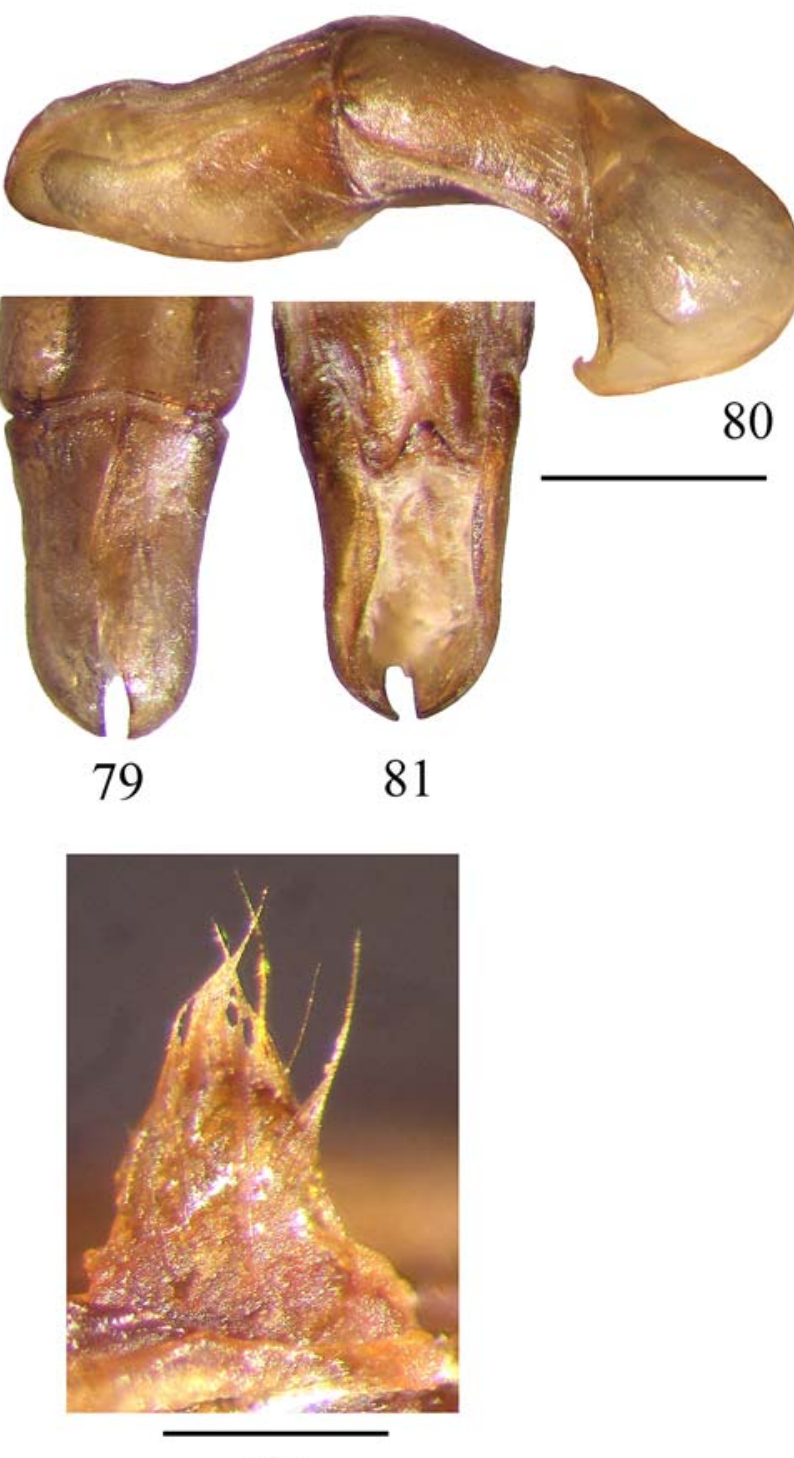

83 
convex, shining. Head dark cherry-red with vertex posteriorly black; pronotum blackish, with pale margins and incomplete medial streak; elytra testaceous with longitudinal blackish marks covering most of their surface; propygidium and pygidium testaceous with dark-brown basal border; underside and legs testaceous, distal tips of tibiae more infuscated; tarsi reddish-brown; antennae reddish-testaceous, mouth parts reddish-brown; pilosity pale.

Clypeus transverse, with front angles broadly rounded and anterior margin weakly raised, rugopunctate; frontovertex densely and coarsely punctate, punctures becoming sparser in posterior half of vertex; frontoclypeal suture complete, very weakly concave. Eyes comparably small, their combined width less than width of clypeus. Antennal club slightly longer than segments 2-6 combined; last joint of maxillary palpi elongately fusiform, with a weakly delimited field of microgranulations on its outer surface and with a patch of minute sensillae at tip. Pronotum twice as broad as long, broadest in middle, with sides much more convergent anteriorly than posteriorly; front angles pointed, hind angles obtuse and broadly rounded; basis completely bordered; no longitudinal medial sulcus. Pronotum rather coarsely and densely punctured; spaces between punctures on disc not exceeding the diameter of points; punctures becoming somewhat denser toward the sides. Scutellum broadly rounded at tip, finely and irregularly punctate. Elytra nearly parallel, 1.55 times as long as broad; punctate rows impressed; intervals weakly and uniformly convex; second and fourth interspaces with a row of punctures similar to those in punctate rows, and a short additional row of punctures in second interspace in its basal one-fifth of length; remaining interspaces bearing very sparse and minute points and microgranulations only. Epipleura long, reaching toward the apex, setose; membranous apical border rather narrow and short, extending anteriorly to a level of third abdominal sternite. Propygidium completely covered by elytra, very finely punctate to rugop- unctate; pygidium weakly convex, finely but tightly punctate, glabrous, except a short row of moderately long and sparse hairs at apex. Sterna finely and not densely punctured, punctures setigerous, bearing short, adpressed hairs; a row of long semierect setae margined the disc of metasternum in its posterior half; disc of metasternum bare and smooth, nearly flat but with longitudinal furrow. Prosternal and mesometasternal processes absent. Abdominal sternites very finely but densely punctate at uppersides, becoming almost smooth medially; each but last sternite possessing a transverse submedial row of short and sparse adpressed setae disappearing in the middle; last abdominal sternite with a row of longer hairs along posterior margin. Sides of abdominal sternites non-carinate.

Fore tibia bidentate, teeth pointed, basal tooth welldeveloped; inner spur long, orientated forward and laterad, attached at the level of basal tooth. Last joint of fore tarsi weakly dilated distally, with a strong anteriorly directed process at mid-length of its ventral margin; inner claw not very broad, deeply clefted, with lower lobe approximately 1.5 times broader than upper one (Fig. 78). Dorsal margin of mesotibia between the second transverse crest and distal margin of mesotibia with a number of long and rather stout setae. Outer middle claw clefted. Meso- and metatibia not very broad or fusiform. Hind tarsi longer than metatibia.

Parameres, as on Figs 79-81. Spiculum gastrale lacking a medial strut. Inner sac of aedeagus without internal sclerites.

Female. Length $10 \mathrm{~mm}$, greatest width $5.5 \mathrm{~mm}$. Front somewhat rugopunctate. Elytra weakly dilated posteriorly, 1.3 times as long as broad; additional row of punctures in the second interspace extends to a basal half of its length. Distal tooth of protibia longer; last joint of fore tarsi thin, with ventral margin indented at mid-length; outer fore claw not dilated (Fig. 82). Vaginal styli subtriangular, hairy (Fig. 83).

Variations. Length $9.0-9.5 \mathrm{~mm}$, greatest width $4.0-5.0$ $\mathrm{mm}$ (males); 9.0-11.0 (usually 10.0-10.5) and 4.0-6.0 (usu-
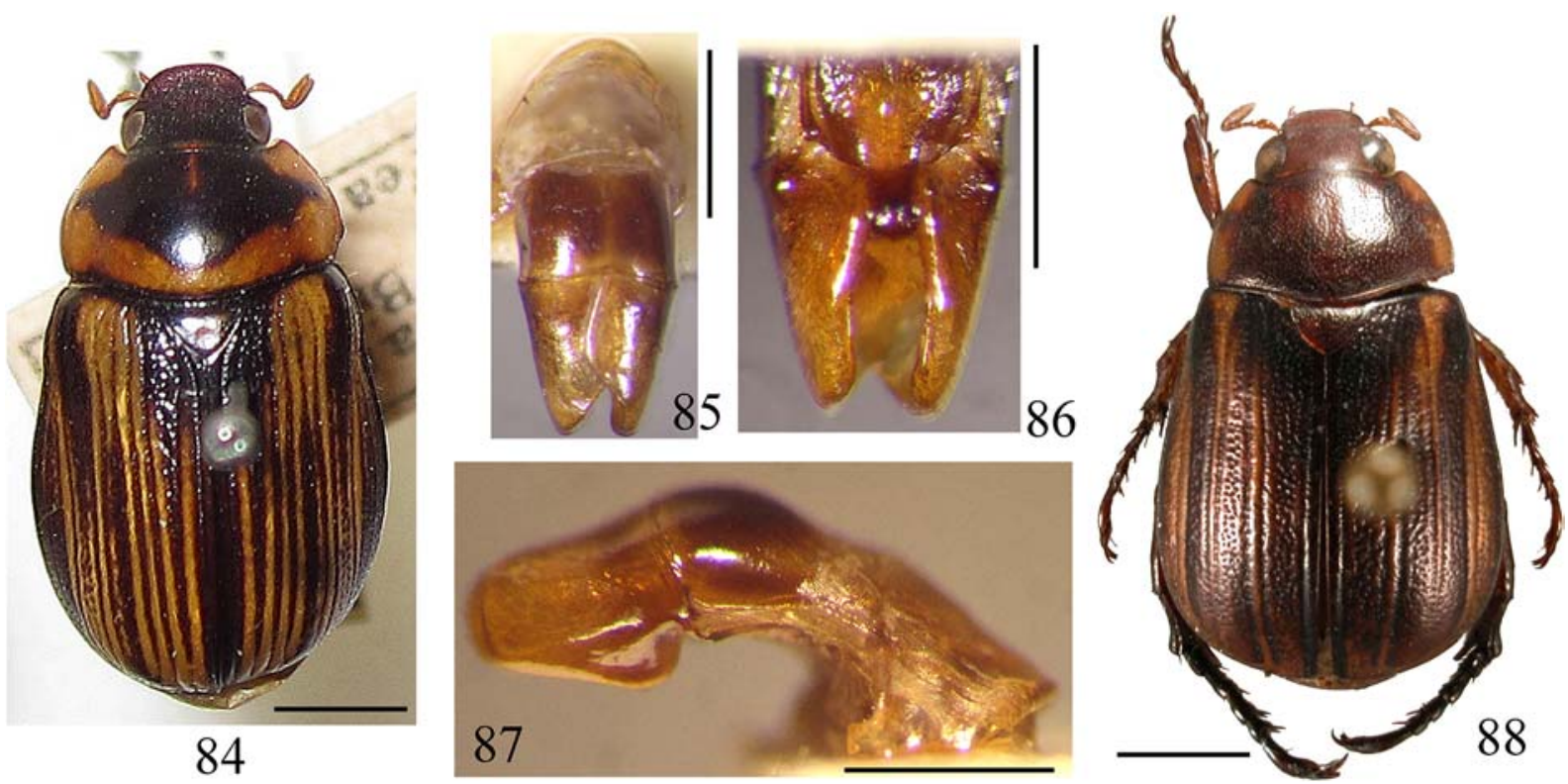

Figs 84-88. Anomala spp: 84-87-A. erosa Arr., ZMB specimen compared with types by Arrow; 88 - A. controversa Hope, type (photo with courtesy of C. Zorn); 84, 88 - dorsal view; 85-87 - aedeagus; 85 - dorsal view; 86 - ventral view; 87 - lateral view. Scale bars: $84,88-3 \mathrm{~mm}, 85-87-1 \mathrm{~mm}$.

Рис. 84-88. Anomala spp: 84-87 - A. erosa Arr., экземпляр из Берлинского музея, сравненный Эрроу с типом; 88 - A. controversa Норе, тип (фото К. Цорна); 84, 88 - вид сверху; 85-87 - эдеагусж; 85 - сверху; 86 - снизу; 87 - сбоку. Масштаб: 84,88 - 3 мм, $85-87-1$ мм. 
ally 5.0-5.5) $\mathrm{mm}$ (females). Dorsal pattern somewhat variable in distribution of black coloration on elytra. Front punctate to rugopunctate, and additional row of punctures in the second interspace of elytra varies from few point to about a half-length of elytron in both sexes. Females generally slightly larger and broader than males, with elytra weakly dilated toward the apex.

ETYMOLOGY. The name of this species is derived from the Latin words "mancus" (incomplete) and "pullus" (dark), due to its characteristic dorsal coloration.

DIFFERENTIAL DIAGNOSIS. Resembles A. erosa Arrow, 1912 and A. controversa Hope, $1845 *$ (Figs 84-88), but differs in the following traits: size smaller $(11.5-14.5 \mathrm{~mm}$ in the compared species); elytra narrower and almost parallelsided (vs. distinctly dilated posteriorly in the compared species), with interspaces impunctate or with a single complete row of punctures ( 2 and 4 ) (vs. punctures coarse and numerous in all the interspaces, with numerous irregular rows of punctures along all length of interspaces 2 and 4 ). In addition, A. controversa possesses clearly larger eyes (their combined length exceeds the width of clypeus), the pronotum with slight medial longitudinal impression and the rather unevenly convex interspaces of elytra in contrast to the new species. The male genitalia of $A$. erosa are fairly different from those in the new species (compare Figs 79-81 and 85-87); the males of $A$. controversa are not known.

\section{Anomala noctibibo Prokofiev, sp.n. Figs 89-95.}

MATERIAL. Holotype, ơ, Vietnam, Binh Thuan prov., vicinity of Mui Ne city, rainy night, 27-29.04.2009, leg. A.M. Prokofiev (ZMMU).

DESCRIPTION. Male, holotype (Fig. 89). Length 14.5 $\mathrm{mm}$, greatest width $7.5 \mathrm{~mm}$. Elongate ovoid, moderately convex. Pale reddish-brown, with head dark cherry-red, tarsi and tibiae more infuscated; teeth of fore tibia blackish; underside testaceous; pilosity pale.

Clypeus transverse, subrectangular, with broadly rounded, indistinct front angles and moderately raised outer margin, sharply delimited from the rest of head, forming nearly straight angle with ocular canthus (Fig. 90). Clypeus coarsely rugopunctate; anterior part of front tightly and coarsely punctate, punctures becoming much sparser on posterior part of front and vertex; frontoclypeal suture complete, weakly concave. Eyes large and bulging, their combined width exceeding interocular distance (Fig. 90). Antennal club longer than segments 2-6 combined; last joint of maxillary palpi fusiform, with narrowed and truncated tip bearing microsensillae. Pronotum 1.7 times as broad as long, broadest at middle. Sides of pronotum rather gently rounded, more convergent anteriorly than posteriorly; front angles short and pointed, hind angles obtuse and broadly rounded; basal border indistinct on short distance before the middle of scutellum; sides of pronotum with a row of sparse long hairs. Pronotum finely punctated, more sparsely on disc than at sides; a small, longitudinally elongate, sulcate impression before scutellum. Scutellum broadly rounded, finely but rather tightly and regularly punctated. Elytra 1.3 times as long as broad, very weakly expanded posteriorly, densely, not very coarsely punctate and sligltly transversely rugose; punctures becoming smaller toward the sides; punctate rows being indistinguishable. Sides of elytra on a short distance behind humeral umbones impressed and flattened. Epipleura of elytra long, bearing a row of rather long sparse hairs; membranous apical border moderately developed. Propygidium almost completely covered by elytra, finely rugopunctate; pygidium moderately convex, rugose, completely covered with rather long, sparse, semierect hairs. Sterna finely punctate, densely covered with moderately long decumbent hairs. Prosternal and mesometasternal processes absent. Disc of metasternum very weakly impressed, almost impunctate, bare, bearing a thin medial furrow. Abdominal sternites finely rugopunctate on uppersides, becoming smooth medially. Uppersides covered by moderately short and sparse adpressed hairs, arranging into a row medially on each sternite but disappearing toward the midventral line; last abdominal sternite with a row of quite long and dense hairs along posterior margin. Sides of abdomen non-carinate.

Fore tibia with two pointed teeth; basal tooth large; inner spur orientated forward and laterad, attached at the level of basal tooth. Last joint of fore tarsi weakly dilated apically, its ventral margin bearing a sharp anteriorly directed spine at middle; inner fore claw deeply clefted, with lower lobe approximately 1.5 times broader, its lower edge excavated at base (Fig. 91). Outer middle claw clefted, lower lobe approximately 1.5 times broader. Middle tibiae thin; hind tibiae considerably expanded distally. Middle and hind tarsi longer than their tibiae.

Parameres, as on Figs 92-94; spiculum gastrale, as on Fig. 95.

Female unknown.

ETYMOLOGY. This species is named from the Latin words "noct" (night) and "bibo" (reveller, roisterer); noun in apposition.

DIFFERENTIAL DIAGNOSIS. This peculiar nightadapted species shows some external resemblances to some members of the highly artificial "micans"-group of Paulian [1959] (i.e. A. igniceps Arrow, 1917), but the male genitalia are extremely different and show a general resemblance to those of the members of the externally very different $\mathrm{cu}$ pripes-group of Lin [1996b]. This species is perhaps related to $A$. rhynchophalla sp. nov. having a similar oven-forkshaped basal plate of the aedeagus. It differs from the latter species in the pale coloration, strikingly enlarged eyes and antennal club, almost rectangular clypeus, and shape of the parameres (see description of $A$. rhynchophalla below).

\section{Anomala nubeculosa ephemeritaenia Prokofiev, ssp.n.} Figs 96-104.

MATERIAL. Holotype, $\sigma^{7}$, Vietnam, Lam Dong prov., Bi Doup - Nui Ba National Park, Hong Giao Pass, $12^{\circ} 10^{\prime} 58^{\prime \prime} \mathrm{N}, 106^{\circ} 42^{\prime} 50^{\prime \prime} \mathrm{E}$, alt. $1625 \mathrm{~m}$, on light, 23-24.04.2012, leg. A.M. Prokofiev (ZMMU). Paratypes, $225 \sigma^{7} \sigma^{7}, 265 \circ 0$, Lam Dong prov., Bi Doup — Nui Ba National Park, Hong Giao to Da Nhim, alt. 1500-1700 m, on light, 13.05.2009, 14-24.04.2010, 22-24.04.2012, 29-31.05.2012, leg. A.M. Prokofiev (ZMMU); $2 \sigma^{\top} \sigma^{\top}, 2$, 9 , Mt. Bi Doup, April 2012, leg. A.E. Anitshkin (ZMMU). Genitalia were studied in $850^{7} \sigma^{7}$.

DESCRIPTION. All the structural characters identical to those described for the nominotypical subspecies [Ohaus, 1905: 84] but the male parameres are different (Figs 100-103).

ETYMOLOGY. The name is based on the changeable coloration which is drastically fading after killing with complete disappearance of the characteristic longitudinal stripes.

* A. controversa described from "Kanton" is a mysterious species, as this name cannot be associated with any living population. The type is a female; however, it looks different from all the species around A. varicolor, being most similar to A. erosa. Paulian [1959] has grossly misidentified this species and confused it with a yet undescribed and extremely different species closely related to $A$. spiloptera Burmeister, 1855, causing a lot of further confusion about $A$. controversa [Zorn, in litt.]. 
DIFFERENTIAL DIAGNOSIS. Differs from the nominotypical subspecies in the structure of the male parameres (see Figs 100-103 and 106-109): the parameres shorter in the new subspecies, subequal (vs. right paramere much longer in the nominotypical form), more or less smoothly rounded (vs. right paramere being distinctly produced at tip and left paramere angulate with frontal margin abruptly sloping and distinctly concave in the nominotypical form), and the ventral process of left paramere being short, almost equal to the length of paramere in the new subspecies, but significantly exceeding the length of paramere in the nominotypical form. The new subspecies is identical in all external characters to the nominotypical form [see Ohaus, 1905], but the living coloration is not known for the latter; thus, color differences cannot be excluded. See Remarks for discussion.
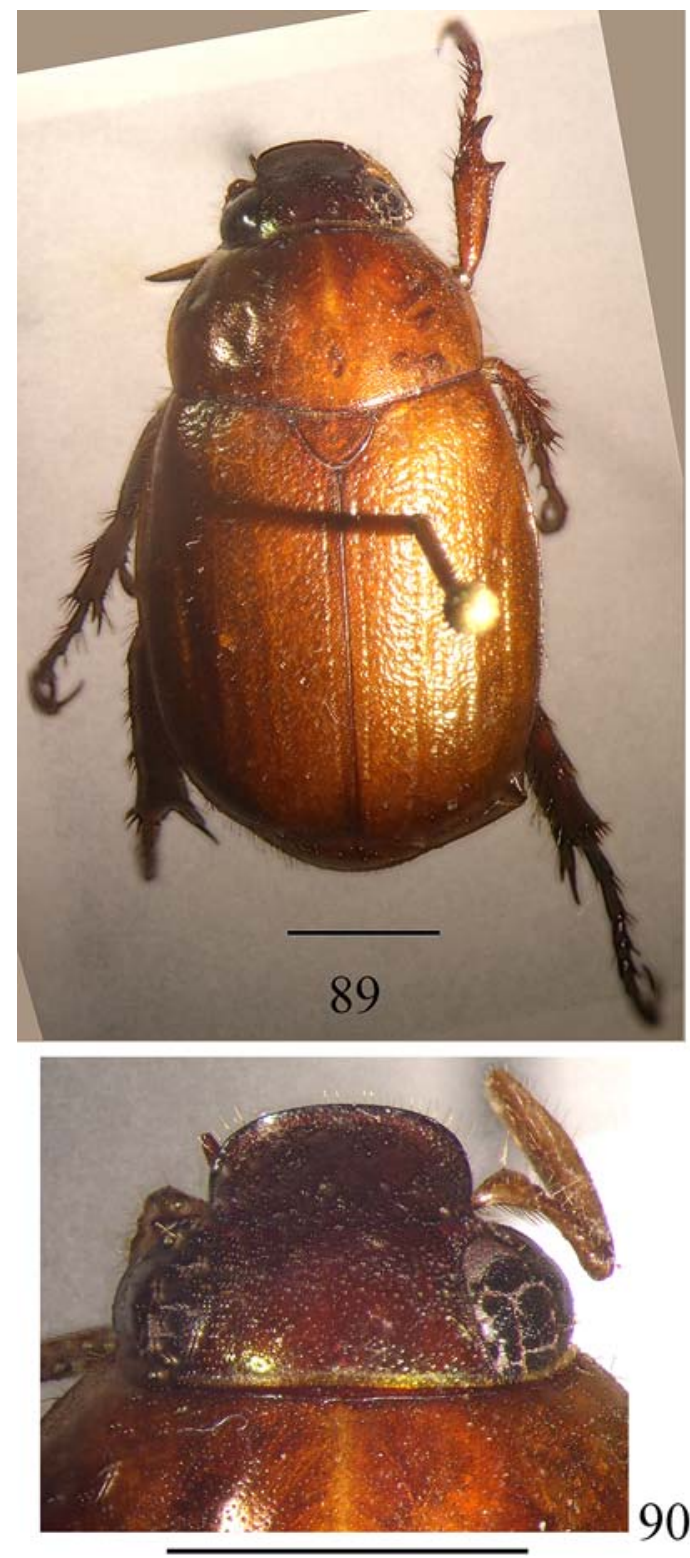

REMARKS. This species shows drastic changes in coloration after killing by chemicals (see Figs 96-98). The living coloration is bright egg-yellow to silvery-yellow, with a variably developed greenish-brown pattern on the pronotum and underside and with three longitudinal bands on the elytra, golden-yellow to brownish-yellow in color; the pygidium bears two pairs of black spots. After a minimal influence of the acetic ether or chlorophorm the coloration becomes radically faded with pattern declining to inconspicuous brownish-gray or even to nearly uniformly yellowish-testaceous coloration; the beetles killed by ammonium have changed coloration also. Only the specimens died in the sun without any chemical agents have kept the coloration close to the living ones; it becomes paler and less pronounced after few years of storage. I did not see the living coloration of the nominotypical form, but most of the museum specimens

Figs 89-95. Anomala noctibibo sp.n., holotype: 89 — dorsal view; 90 - head, dorsal view; 91 — fore tarsus; $92-94$ — aedeagus; 92 dorsal view; 93 - lateral view; 94 - ventral view; 95 - spiculum gastrale. Scale bars: $89,90-3 \mathrm{~mm}$, others - $1 \mathrm{~mm}$.

Рис. 89-95. Anomala noctibibo sp.n., голотип: 89 - вид сверху; 90 - голова, сверху; 91 — передняя лапка; 92-94 — эдеагус; 92 - вид сверху; 93 - сбоку; 94 - снизу; 95 - spiculum gastrale. Масштаб: 89, 90 - 3 мм, прочие - 1 мм. 
show a more or less distinct spotted pattern with the irregular spots arranged and/or variably confluent into three bands on

the same manner as in the new subspecies (Fig. 105). This might indicate the small color differences between the sub-
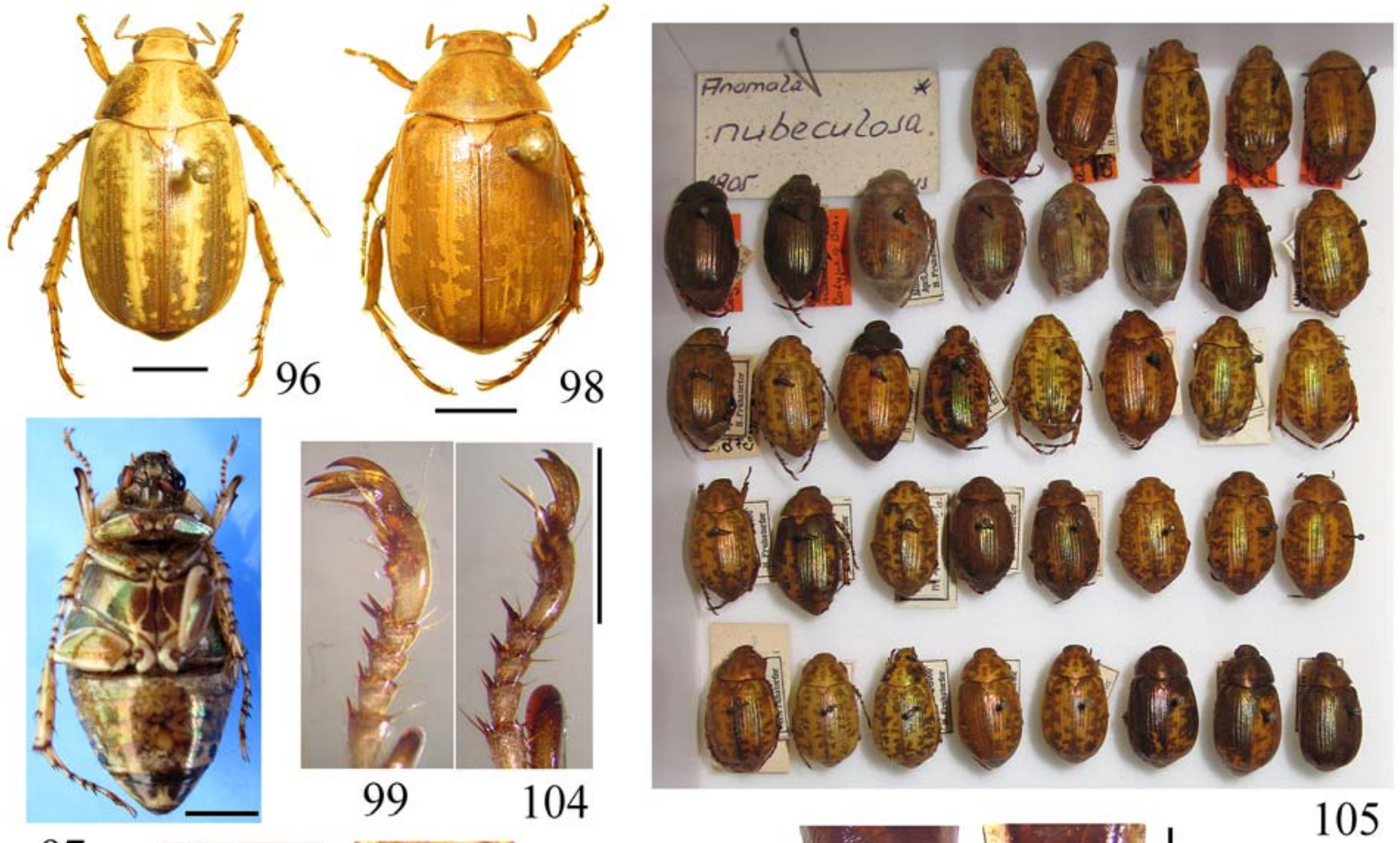

97
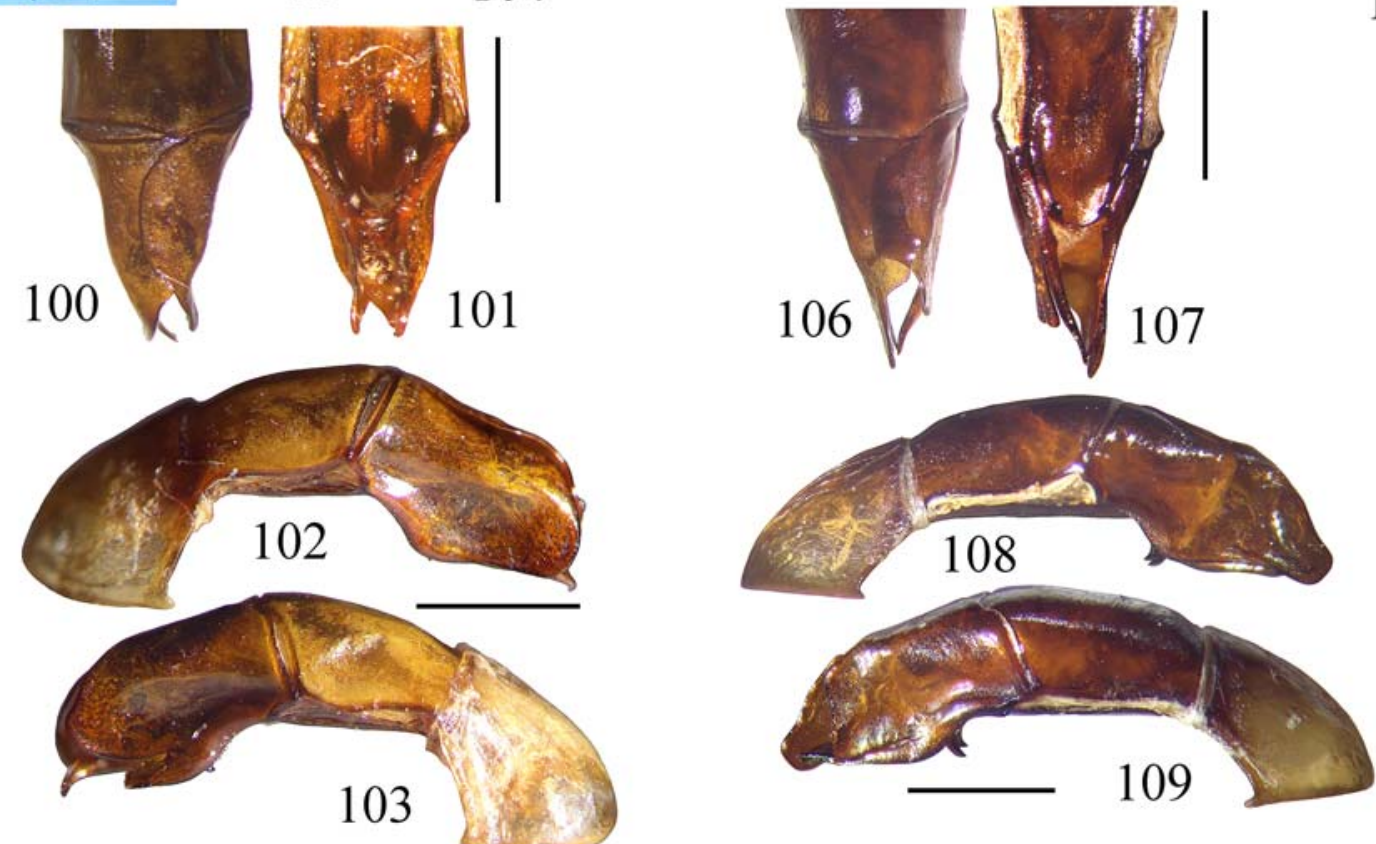

Figs 96-109. Anomala nubeculosa sspp: 96-104 - A. n. ephemeritaenia ssp.n.; 105-109 - A. n. nubeculosa Ohs.; 96 - holotype, dorsal view; 97 - holotype, ventral view, photographed immediately after killing; 98 — paratype, after killing by acetic ether; 99 , 104 fore tarsus (99 - holotype; 104 — female paratype; scale bar common); 100-103 — holotype, aedeagus (100 — dorsal view; 101 — ventral view; 102 - lateral view, right side; 103 - lateral view, left side; scale bar common); 105 — a series of beetles from Tonkin in Ohaus collection (ZMB) showing the dorsal color pattern; 106-109 — syntype, aedeagus (106 — dorsal view; 107 — ventral view; 108 - lateral view, right side; 109 - lateral view, left side; scale bar common). Scale bars: 96-98 - $3 \mathrm{~mm}$, others - $1 \mathrm{~mm}$.

Рис. 96-109. Anomala nubeculosa sspp: 96-104 - A. n. ерhemeritaenia ssp.n.; 105-109 - A. n. nиbeculosa Ohs.; 96 - голотип, вид сверху; 97 - голотип, снизу, сфотографирован свежеумерщвленный жук; 98 - паратип, заморен этилацетатом; 99 , 104 передняя лапка; 99 - голотип; 104 - паратип, самка (линейка общая); 100-103 - голотип, эдеагус; 100 - сверху; 101 - снизу; 102 - сбоку, правая сторона; 103 - сбоку, левая сторона (линейка общая); 105 - серия жуков из Тонкина из коллекции Охауса (ZMB), демонстрирующая изменчивость рисунка верха; 106-109 - синтип, эдеагус; 106 - вид сверху; 107 - снизу; 108 - сбоку, правая сторона; 109 - сбоку, левая сторона (линейка общая). Масштаб: 96-98 - 3 мм, прочие - 1 мм. 
species; however, the historical specimens could be killed by different agents (cyanide or sulphur ether), that may have caused the aforementioned differences.

The subspecies ephemeritaenia appears to be an endemic race of Dalat Plateau. I had examined about a hundred specimens including the types of the nominotypical race from North Vietnam, North and Central Laos and Kachin State in Myanmar (genitalia were studied in $54 \sigma^{7} \sigma^{7}$ ); all these specimens show constant differences in the genitalic characters compared to the specimens from Dalat. This species is also known from the Bu Gia Map National Park in Binh Phuoc province of southern Vietnam [A.E. Anitschkin, personal communication 2012], but I did not see the specimens and their subspecific status is not known.

\section{Anomala phanthietica Prokofiev, sp.n.}

Figs 110-118.

MATERIAL. Holotype, $\mathrm{O}^{7}$, Vietnam, Binh Thuan prov., Le Hong Phong, $\sim 28 \mathrm{~km}$ NW Mui Ne, $\sim 8 \mathrm{~km} \mathrm{~S}$ Lu'o'ng S'on, sands, bush, 8-9.05.2012, on light, A.M. Prokofiev leg. (ZMMU).

Paratypes, $640^{7} 0^{7} 00$, Binh Thuan prov., Le Hong Phong, 18 $29 \mathrm{~km} \mathrm{NW}$ Mui Ne and around Mui Ne city, sands, bush, 27 29.04.2010 and 8-11.05.2012, on light, A.M. Prokofiev leg. (ZMMU).

DESCRIPTION. Male, holotype (Fig. 110). Length 12 $\mathrm{mm}$; greatest width $6.5 \mathrm{~mm}$. Elongate ovoid, convex, shining.
Testaceous, with head cherry-red, clypeofrontal suture marked by black at sides, anterior and posterior borders of pronotum, scutellum and elytral suture narrowly margined by brownishblack, teeth of protibia and distal end of metatibia darkened, tarsi dark reddish-brown, pilosity yellowish.

Clypeus transverse, broadly semicircular, with indistinct front angles and strongly raised anterior margin, finely rugopunctate; front and anterior half of vertex rather coarsely rugopunctate, becoming finely and moderately densely punctate in posterior half of vertex; frontoclypeal suture well-delimited, complete, concave. Dorsal surface of head bearing very fine and easily worn, sparsely distributed setae. Antennal club weakly longer than segments 2-6 combined; last joint of maxillary palpi elongately fusiform, with a weakly developed field of microgranulations on its outer surface and with a dense patch of minute sensillae at tip. Pronotum twice as broad as long, broadest at base, with sides nearly parallel in basal two-thirds, but strongly convergent in anterior third; front angles pointed, hind angles straight, broadly rounded; basis completely bordered. Pronotum regularly, finely and moderately densely punctured (spaces between punctures being commensurable with diameter of points); sides of pronotum with a row of long hairs. Scutellum broadly rounded, finely punctate, with points being much denser at base and sides. Elytra weakly
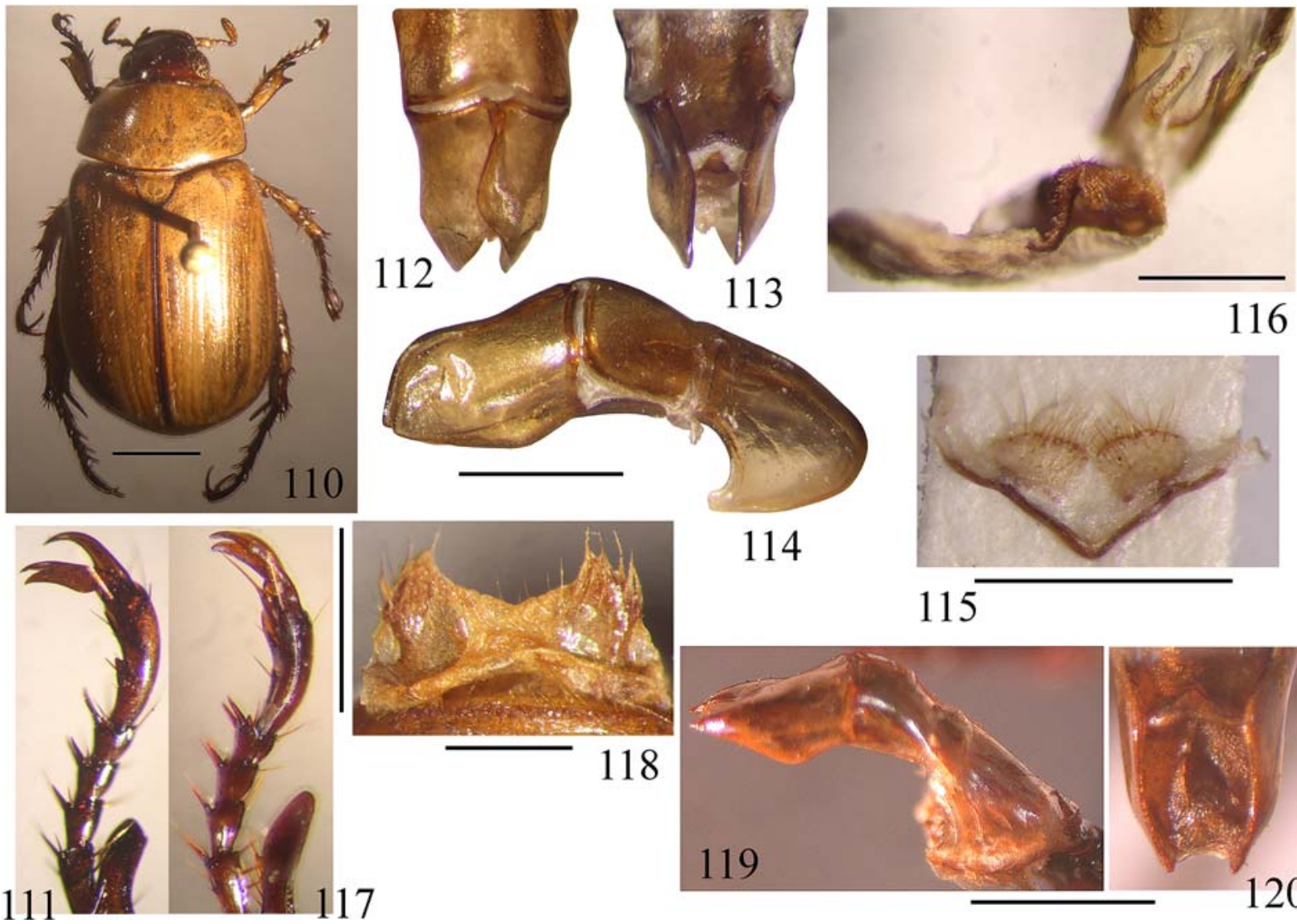

114

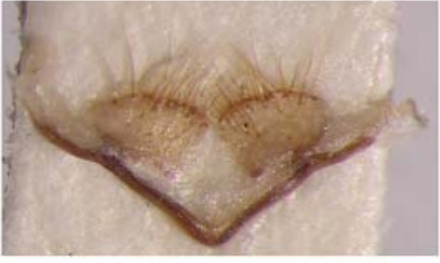

115

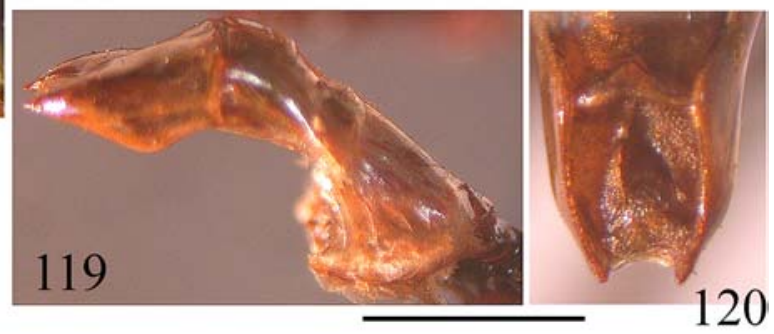

Figs 110-120. Anomala spp: 110-118 - A. phanthietica sp.n.; 110-116 - holotype; 117 and 118 - female paratype; 119 , 120 A. tincticeps, syntype (photos with courtesy of C. Zorn); 110 - dorsal view; 111, 117 - fore tarsus (scale bar common); 112-114 and 119, 120 - aedeagus; 112 - dorsal view; 113,120 - ventral view; 114,119 - lateral view (scale bars common); 115 - spiculum gastrale; 116 - sclerite of the inner sac; 118 - vaginal styli. Scale bars: $110-3 \mathrm{~mm}, 118-0.5 \mathrm{~mm}$, others $-1 \mathrm{~mm}$.

Рис. 110-120. Anomala spp: 110-118 - A. phanthietica sp.n.; 110-116 - голотип; 117 и 118 - паратип, самка; 119, 120 - A. tincticeps, синтип (фото К. Цорна); 110 - сверху; 111, 117 — передняя лапка (линейка общая); 112-114 и 119,120 - эдеагус 112 - сверху; 113, 120 - снизу; 114, 119 - сбоку (линейки общие); 115 - spiculum gastrale; 116 - склерит внутреннего мешка; 118 - вагинальные стили самки. Масштаб: $110-3$ мм, $118-0.5$ мм, прочие - 1 мм. 
broadened posteriad, 1.2 times as long as broad; punctate rows well-discernible, not impressed, interspaces flat, but first (sutural) one convex; second interspace broad, irregularly punctate in basal half, with punctures arranged in a row posteriad, these punctures as coarse as in punctate rows; remaining disc of elytra bearing very sparse minute points and microgranulations only, but punctures in interspaces becoming as coarse as those of punctate rows from fourth interspace laterad. Epipleura long, reaching toward the apex, with a row of rather sparse, moderately long setae along all their length; membranous apical border moderately broad. Propygidium finely rugopunctate; pygidium moderately convex, densely but not coarsely punctate, bare, except sparse long hairs at apex. Sterna rather coarsely and densely punctured, covered with short, adpressed hairs. Disc of metasternum longitudinally impressed, bare and smooth. Prosternal and mesometasternal processes absent. Abdominal sternites tightly and coarsely punctate; each but last sternite possessing a transverse mesial row of moderately long sparse adpressed setae; last abdominal sternite with a row of rather long hairs along posterior margin. Sides of abdominal sternites non-carinate.

Fore tibia bidentate, teeth long and pointed; inner spur long, orientated forward and downward, attached at the level of basal tooth. Last joint of fore tarsi weakly dilated distally, with a small but well-expressed medial tooth on its ventral margin; inner claw not very broad, clefted, with lower lobe approximately 1.5 times broader than upper one (Fig. 111). First and especially second transverse crests on the outer side of mesotibia with long spines; dorsal margin of mesotibia between the second and third (distal margin of mesotibia) transverse crests with a row of long hairs. Outer middle claw clefted. Hind tarsi longer than metatibia.

Parameres, as on Figs 112-114. Spiculum gastrale lacking a medial strut (Fig. 115). Inner sac of aedeagus with an only sclerite bearing a carpet-like patch of setae (Fig. 116).

Female. Length $12.5 \mathrm{~mm}$, greatest width $6.5 \mathrm{~mm}$. Slightly darker than the male holotype. Elytra slightly more expanded caudally than in the male holotype, 1.4 times as long as broad. Anterior tooth of fore tibiae longer and more curved than in male. Last joint of fore tarsi thin, with a weak trace of medial tooth on its ventral margin; outer fore claw not dilated, with subequal lobes (Fig. 117). Vaginal styli subtriangular, with broadly rounded and strongly hairy apex (Fig. 118).

Variations. Length $12.0-14.0 \mathrm{~mm}$, greatest width $5.5-$ $6.5 \mathrm{~mm}$. Sometimes with a slight reddish tint dorsally, and with meso- and especially metatibiae more infuscated distally that described for the holotype. Clypeofrontal suture occasionally indicated by black. Antennal club as long as to very weakly longer than segments $2-6$ combined. Sexual dimorphism expressing in the shape of anterior tooth protibia and last joint of fore tarsi and its inner claw as described above; also females being slightly broader and commonly darker than males; other features vary independently from sex.

ETYMOLOGY. This species is named after Phan Thiet City, a capital of Binh Thuan Province.

DIFFERENTIAL DIAGNOSIS. Externally undistinguishable from the Burmese species A. tincticeps Arrow, 1917, but with different male genitalia (compare Figs 113 114 and 119-120). In the new species the apices of parameres are truncated (vs. sharply pointed) in lateral view, and the distal margin of the basal plate is much less recurved. See key above for the differences from the similar species in the region.

\section{Anomala rhynchophalla Prokofiev, sp.n.} Figs 121-127.

MATERIAL. Holotype, $\sigma^{7}$, Vietnam, Binh Thuan prov., $\sim 30$ $\mathrm{km}$ SW Phan Thiet, Ca Pet - Song Mong, $11^{\circ} 01.156^{\prime} \mathrm{N}, 107^{\circ} 52.218^{\prime}$ E, alt. $\sim 100 \mathrm{~m}, 11-12.05 .2012$, on light, A.M. Prokofiev leg. (ZMMU).

Paratypes, $14 \sigma^{\top} \sigma^{\top}, 5+0$, collected with the holotype; 1 , , Vietnam, Phu Quy I., west coast, 22.03.2010, on light of house lamp, leg. A.M. Prokofiev (ZMMU).

DESCRIPTION. Male, holotype (Fig. 121). Length 17.5 $\mathrm{mm}$, greatest width $9.5 \mathrm{~mm}$. Brownish-green, lustrous, sides of pronotum broadly margined by yellow; propygidium testaceous, with a large dark-greenish patch; pygidium testaceous, with a small dark-greenish patch at middle of its base; underside, coxae and femora testaceous with reddish tint; tibiae and tarsi metallic brownish-green; antennae and mouthparts reddish-brown, with club bicolorous, as its basal and apical tips much more infuscated; pilosity pale.

Clypeus transverse, with broadly rounded front angles and straight, deep and moderately raised anterior margin, tightly and coarsely rugopunctate; anterior half of front rugopunctate, becoming tightly punctured posteriad, punctures on vertex becoming smaller and sparser posteriad; frontoclypeal suture complete, almost straight. Antennal club equals to segments 2-6 combined; last joint of maxillary palpi elongately fusiform, with an impressed field of microgranulations at basal half of its outer surface and with a dense patch of minute sensillae at tip. Pronotum twice as broad as long, broadest at middle, with sides much more convergent anteriorly than posteriorly; front angles pointed, hind angles obtuse, rounded; basal border interrupted before scutellum. Pronotum regularly, densely and coarsely punctured (spaces between punctures being commensurable with diameter of points or nearly so); sides of pronotum in posterior half with a row of few very long hairs. Scutellum broadly rounded, coarsely punctate, with points being slightly smaller and much denser at outer margin. Elytra weakly broadened posteriad, 1.2 times as long as broad; punctate rows indistinct except the first one; punctures rather small but coarse, somewhat irregular, becoming denser and smaller toward the sides and apex; interspaces between punctures in second and fourth elytral interspace and close to sides and apex of elytra being variably rugose. Epipleura long, reaching toward the apex, bearing a row of moderately short, well-spaced setae along almost all their length; membranous apical border moderately broad. Propygidium finely transversely rugose, with very sparse and inequal setosity; pygidium moderately convex, finely rugopunctate, covered by moderately long and sparse setae but bare at center. Sterna very shallowly punctured, punctures setigerous, bearing moderately long, adpressed hairs, except in the middle of disc of metasternum, which is smooth and glabrous, weakly impressed. Prosternal and mesometasternal processes absent. Abdominal sternites very finely rugopunctate at uppersides, becoming very finely and sparsely punctate mesiad; uppersides with several rows of moderately short, adpressed hairs; each but last sternite possessing a transverse mesial row of moderately long sparse setae; last abdominal sternite with a row of long hairs along posterior margin. Sides of abdominal sternites non-carinate.

Fore tibia bidentate, teeth long and pointed; inner spur long, orientated forward and laterad, attached at the level of basal tooth. Last joint of fore tarsi dilated apically, with a pronounced triangular medial tooth on its ventral margin; inner claw clefted, with lower lobe twice broader than upper one, its ventral margin deeply excavated at base (Fig. 122). First and second transverse crests on the outer side of mesotibia with long stout spines; dorsal margin of mesotibia 
between the second and third (distal margin of mesotibia) transverse crests with a row of very long and rather stout spines, outside from them surface being little swelled, but not forming a distinct longitudinal carina. Outer middle claw clefted, lower lobe approximately 1.5 times broader. Metatibia broadened; hind tarsi longer than metatibia.

Aedeagus, as on Figs 123-125.

Female. Length $17.5 \mathrm{~mm}$, greatest width $10 \mathrm{~mm}$. Distal tooth of protibia slightly longer and blunter; inner spur attached just behind the basal tooth. Last joint of fore tarsus less dilated apically than in male and lacking a ventral tooth (Fig. 126). Lower lobe of inner fore claw approximately 1.5 times broader than upper one, its ventral margin straight. Vaginal styli large, triangular, apically pilose (Fig. 127).

Variations. Length $16-18 \mathrm{~mm}$, greatest width $8.5-10 \mathrm{~mm}$ (males), 17.0-18.0 $\mathrm{mm}$ and $9.5-10.0 \mathrm{~mm}$ (females). Elytra 1.0-1.2 times as long as broad. Clypeus and anterior half of front rugopunctate to very closely punctate, punctures always becoming smaller and sparser posteriad. Degree of rugosity of elytra varies in great extent. Propygidium sometimes fully testaceous; pygidium varies from fully testaceous to testaceous with large triangular metallic green patch at base; antennal club usually unicolorous, reddish-brown to testaceous-brown.

ETYMOLOGY. This species is named after the Greek words "rhynchos" (proboscis) and "phallus" (penis), due to its characteristic shape of the aedeagus.

DIFFERENTIAL DIAGNOSIS. Similar to A. noctibibo Prokofiev sp.n. in the male genitalic characters but the parameres are much longer and beak-shaped; further differs from the aforementioned species in the absence of the night-adapted complex of characters (enlarged eyes and antennal club, subrectancular clypeus in $A$. noctibibo), in the coloration, and in the pilosity of the pygidium, which is shorter and disappearing at disc in A. rhynchophalla in contrast to A. noctibibo.

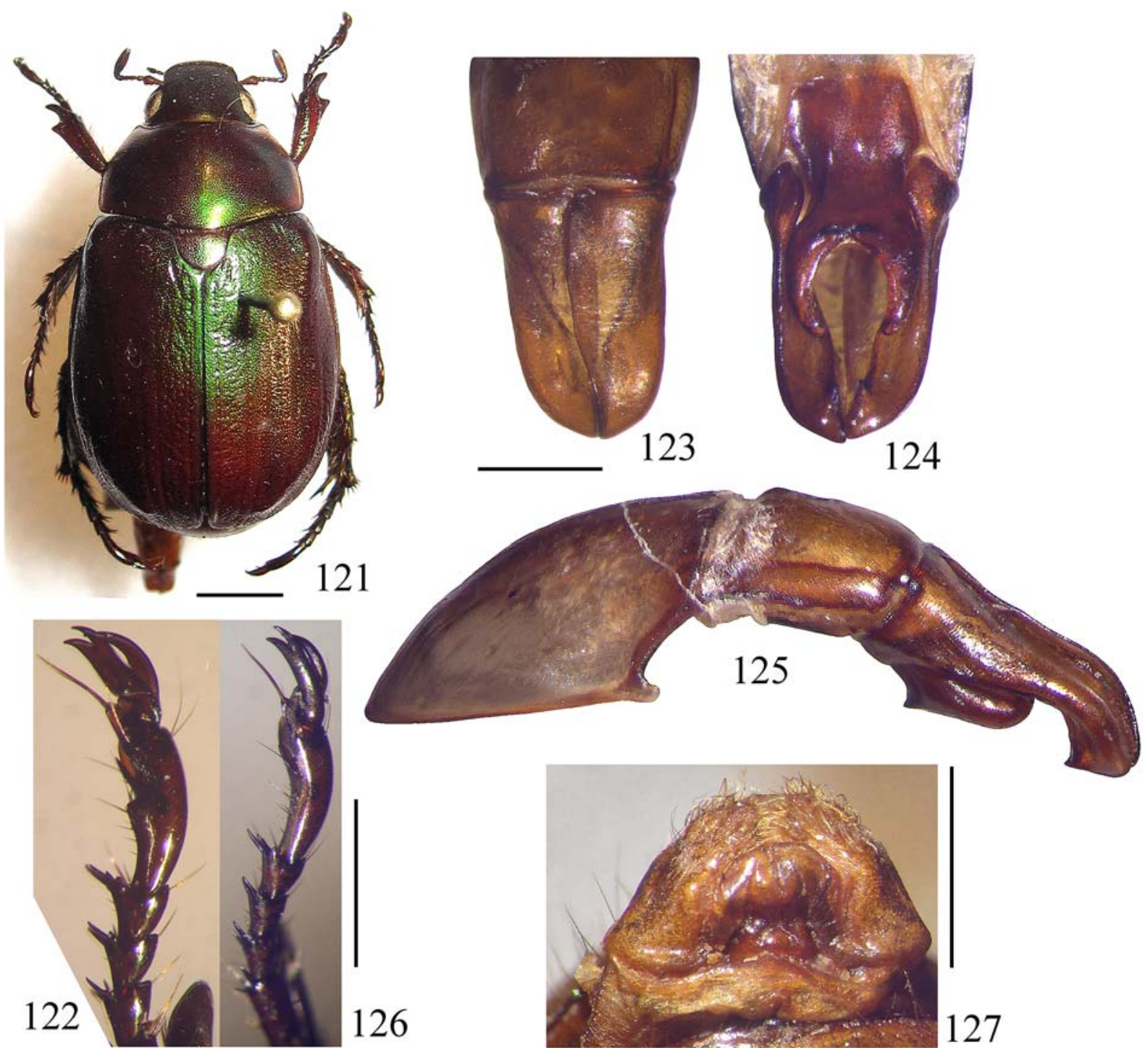

Figs 121-127. Anomala rhynchophalla sp.n.: 121-125 — holotype; 126-127 — female paratype; 121 — dorsal view; 122, 126 - fore tarsus (scale bar common); 123-125 — aedeagus; 123 — dorsal view; 124 — ventral view; 125 — lateral view (scale bar common); 127 vaginal styli. Scale bars: $121-3 \mathrm{~mm}$, others $-1 \mathrm{~mm}$.

Рис. 121-127. Anomala rhynchophalla sp.n.: 121-125 — голотип; 126-127 - паратип (самка); 121 — вид сверху; 122,126 передняя лапка (линейка общая); 123-125 — эдеагус; 123 - сверху; 124 - снизу; 125 — сбоку (линейка общая); 127 — вагинальные стили самки. Масштаб: $121-3$ мм, прочие - 1 мм. 


\section{Anomala zornella Prokofiev, sp.n.}

Figs 128-133.

MATERIAL. Holotype, $0^{7}$, Laos, Khammouane prov., Pakhhene, 01-16.06.2012 (ZMMU).

Paratypes, $110^{7} O^{7}$, 15 우, collected with the holotype (ZMMU); $20^{7} \sigma^{7}$, 3우, Laos, Phongsaly prov., local collector, July 2007 (ZMMU); 2 $9+$, Myanmar, Kachin state, Mt. Emaw Bum, 522.06.2013 (ZMMU); 3ㅇ, NE Laos, Hua Phan prov., Ban Saluei, Phu Phan Mt., 20 $0^{\circ} 3^{\prime}$ N, $103^{\circ} 59^{\prime}$ E, 1300-2000 m, 6-18.04.2004, J. Bezdik leg. (CZ); 10 , NE Laos: Hua Phan prov. Ban Saleui, Phou Pan (Mt.), $\sim 20^{\circ} 12^{\prime} \mathrm{N}, 1^{\circ} 4^{\circ} 01^{\prime} \mathrm{E}, 1300-1900 \mathrm{~m}, 7 . \mathrm{IV} .-25 . V .2010$, leg. C. Holzschuh Ankauf ZFMK Bonn 2011 (ZFMK); $20^{7} \mathrm{O}^{7}, \mathrm{NE}$ Laos: Hua Phan prov., Ban Saleui, Phou Pan (Mt.), $20^{\circ} 12^{\prime} \mathrm{N}$, 10401'E, 1300-1900 m, 1-31.V.2011, leg. C. Holzschuh Ankauf ZFMK Bonn 2011 (ZFMK).

DESCRIPTION. Male, holotype (Fig. 128). Length 12.0 $\mathrm{mm}$; greatest width $7.0 \mathrm{~mm}$. Elongate ovoid, moderately convex; thorax and abdomen regularly concave in profile; strongly shining. Head and pronotum dark-green, metallic, clypeus with cupreous tint anteriorly, sides of pronotum margined by brownish-orange; elytra dark-green on brownish ground, metallic; pygidium reddish-brown with a large metallic-green patch at center; thorax reddish-brown with a large dark-metallic-green area at each side; abdomen reddish-brown with obscure dark-green patches; legs reddish, all tibiae and tarsi with strong cupreous luster; antennae and mouthparts reddish-brown; pilosity pale.

Clypeus transverse, with surface distinctly impressed at sides, with straight, moderately raised and reflexed anterior margin and broadly rounded, indistinct front angles; rather coarsely rugopunctate; front similarly rugopunctate, with large triangular depression; vertex finely and sparsely punctured; frontoclypeal suture conspicuous, complete, concave in middle third but straight at sides. Antennal club slightly longer than segments 2-6 combined; last joint of maxillary palpi elongately fusiform, with a patch of minute sensillae at tip and a weakly defined oval area of striate microsculpture at basal half of the outer side. Pronotum twice as broad as long, broadest at base; sides of pronotum almost parallel in basal two-thirds but strongly convergent anteriad; side margin of pronotum flanged; front angles pointed, sharp; hind angles straight, rounded; basal border complete and very sharply delimited. Pronotum very finely and sparsely punctured; punctures hardly visible at low magnifications; sides of pronotum with a row of few rather short hairs. Scutellum large, subtriangular, rather coarsely but irregularly punctured. Elytra weakly expanded caudally, approximately 1.1 times as long as broad; punctate rows represented by fine and shallow points; second interspace with similar points irregularly distributed; other interspaces with very fine and sparse, hardly traceable points becoming more distinct and tight toward the sides; fourth interspace and some areas close to sides with coarse transverse rugosities. Humeral knobs bulging, lateral margin of elytra weakly callose behind them. Epipleura long, with a row of short and sparse setae at the level of humeral
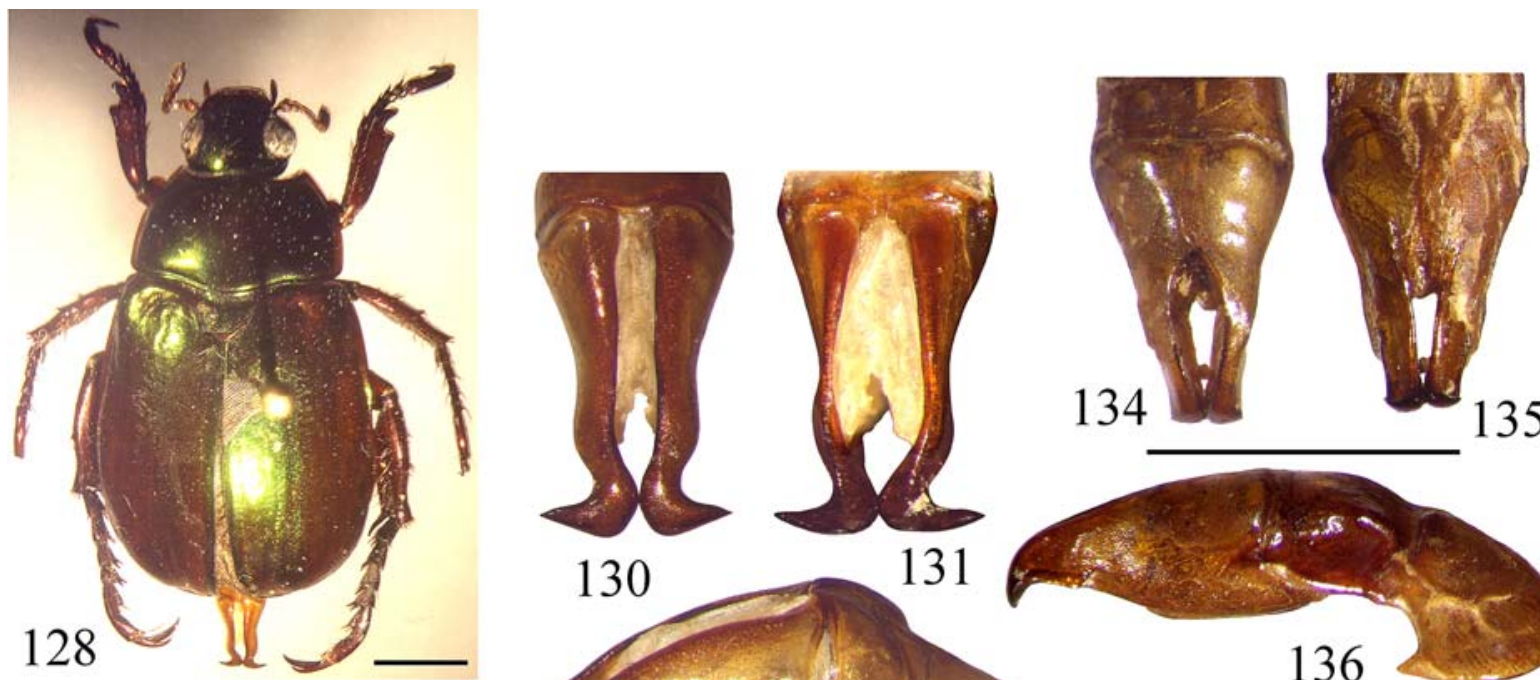

135
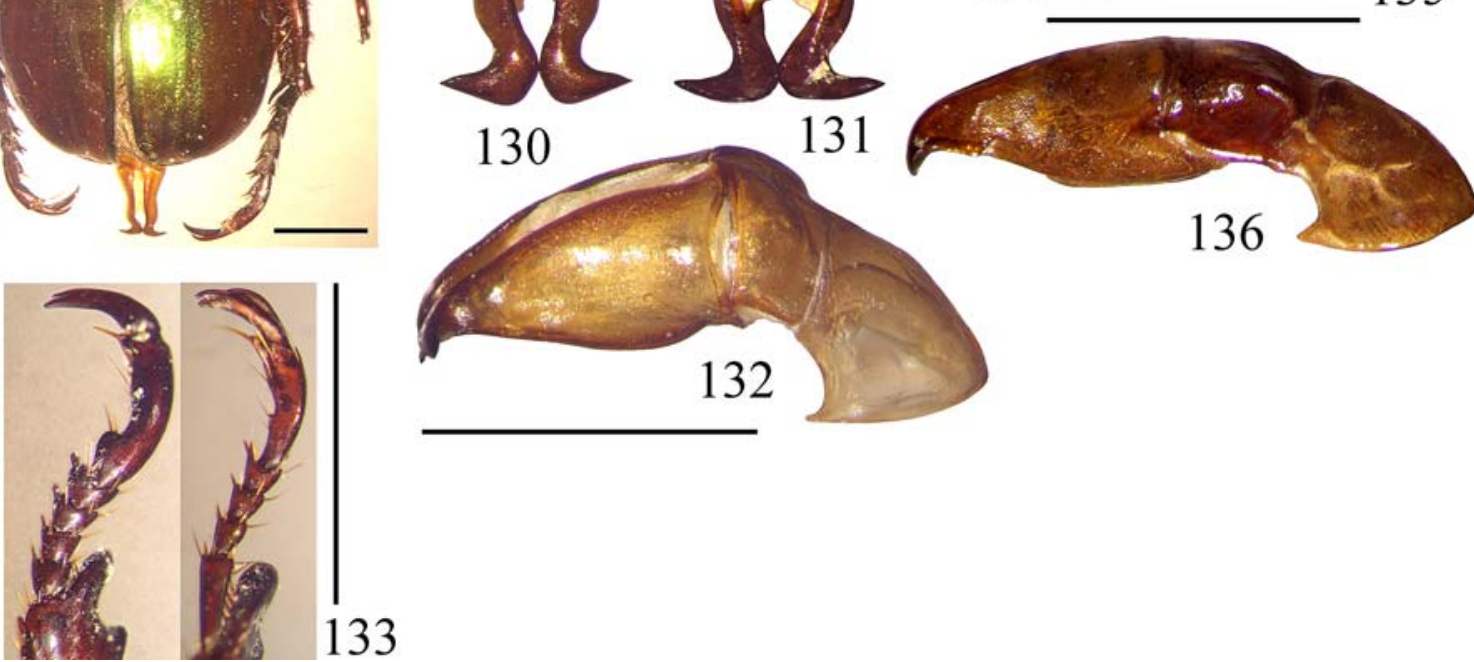

129

Figs 128-136. Anomala spp: 128-133 - A. zornella sp.n.; 128-132 - male holotype; 133 — female paratype; 134-136 - A. rufiventris Redt.; 128 - dorsal view; 129, 133 - fore tarsus (scale bar common); 130-132 and 134-136 - aedeagus; 130, 134 - dorsal view; 131, 135 - ventral view; 132, 136 - lateral view )scale bars common). Scale bars $-3 \mathrm{~mm}$.

Рис. 128-136. Anomala spp: 128-133 - A. zornella sp.n.; 128-132 - голотип; 133 - самка, паратип; 134-136 - A. rufiventris Redt.; 128 - сверху; 129, 133 - передняя лапка (линейка общая); 130-132 и 134-136 — эдеагус; 130, 134 — сверху; 131, 135 — снизу; 132, 136 - сбоку (линейки общие). Масштаб: 3 мм. 
knobs; membranous apical border moderately broad but very long, extending anteriorly toward the hind point of humeral knob. Propygidium completely covered by elytra. Pygidium moderately convex, sparsely punctate; punctures much coarser than on pronotum and elytra. Pygidium bare except several rows of rather long but sparse erect hairs at apex. Sterna finely punctate, covered with moderately sparse and very short adpressed hairs; disc of metasternum weakly concave, with very sparse and short setae posteriorly. Prosternal and mesometasternal processes absent. Abdominal sternites finely rugopunctate at uppersides, sparsely punctate medially; a transverse row of moderately sparse and short setae just behind middle of each but last sternite; last sternite with a row similar setae along posterior margin. Sides of abdomen noncarinate.

Fore tibia bidentate, basal tooth large; inner spur orientated forward and downward, attached at the level of basal tooth. Last joint of fore tarsi apically thickened, with ventral margin toothed at base; inner fore claw clefted, with lower lobe very broad, approximately 2.5 times broader than the upper one; ventral margin of lower lobe with very deep but narrow excision at base (Fig. 129). Outer middle claw clefted, lower lobe twice broader. Meso- and metatibia fusiform, not thickened.

Parameres, as on Figs 130-132.

Female, paratype. Length $13.0 \mathrm{~mm}$, greatest width 7.0 $\mathrm{mm}$. Sides of elytra distinctly callose behind humeral knobs. Teeth of protibia obtuse, basal tooth less expressed than in the male; inner spur attached well behind the level of basal tooth. Last joint of fore tarsi apically dilated, its ventral margin weakly toothed just behind mid-length; inner fore claw less dilated, lower lobe scarcely broader than the upper one, not incised at base (Fig. 133). Lower lobe of outer middle claw approximately 1.5 broader than the upper one. Vaginal styli triangular, apically pilose.

Variations. Length $12.0-13.0 \mathrm{~mm}$, greatest width 6.5 $7.5 \mathrm{~mm}$ (both sexes). Elytra sometimes uniformly bright metallic-green, rarely with orange apical margin; pygidium sometimes metallic-green with brownish-orange outer margin. Impressions on front and clypeus variably developed, sometimes very shallow.

ETYMOLOGY. This species is named in honour of Carsten Zorn (Gnoien, Germany), who made numerous advices in the course of this study and who first recognized this taxon.

DIFFERENTIAL DIAGNOSIS. Closely allied to $\mathrm{A}$. $\mathrm{ru}$ fiventris Redtenbacher, 1843, but size smaller (12.0-13.0 vs. $14.0-20 \mathrm{~mm}$ ), frons impressed, basal border of pronotum much broader and sharper, punctate rows on elytra slightly more pronounced, pilosity of sterna shorter and pygidium mostly glabrous in the new species (vs. completely covered with very long though sparse erect hairs in A. rufiventris), last joint of fore tarsi toothed at base (vs. just behind middle in $A$. rufiventris). The teeth of protibia are much more sharply pointed and the basal tooth is comparably smaller in $A$. rufiventris. The male aedeagi are different (compare Figs 130-132 and 134-136).

REMARKS. This species probably occurs in North Vietnam (Tamdao) also, but the specimens from this locality have legs green in color, although they are identical to the redlegged Laotian specimens in the genitalic structures [Zorn, in litt.].

ACKNOWLEDGEMENTS. I am sincerely indebted to Dr. Carsten Zorn (Gnoien, Germany) for his valuable comments on the identification of certain presently described species and for access to his excellent collection of Oriental Rutelines, to Drs. Olivier Montreuil, Antoine Mantilleri (MNHN, Paris, France), Johannes Frisch and Joachim Willers (ZMB, Berlin, Germany) for the possibility of examination of the collections under their care and numerous assistances during the museum work.

\section{References}

Arrow G.J. 1917. The Fauna of British India, Including Ceylon and Burma. Coleoptera Lamellicornia part II (Rutelinae, Desmonycinae, and Euchirinae) // Taylor \& Francis. London. 387 pp.

Chandra K., Gupta D. 2012. Pleurostict scarabs (Coleoptera: Scarabaeidae): New distributional records in Arunachal Pradesh, north-east India // Check List. Vol.8. No.5. P.889-893.

Lin P. 1996a. New species of Anomala hirsutula species group from China and discussion on their taxonomic problems (Coleoptera: Rutelidae) // Entomotaxonomia. Vol.18. No.3. P.157-169.

Lin P. 1996b. Anomala cupripes species group of China and a discussion on its taxonomy (Coleoptera: Rutelidae) // Entomologica Sinica. Vol.3. No.4. P.300-313.

Nguyen N.T.T., Wada K. 2006. A new species of the genus Mimela (Coleoptera, Scarabaeidae, Rutelinae) from Vietnam // Kogane. No.7. P.61-64.

Ohaus F. 1905. Beiträge zur Kenntnis der Ruteliden // Deutsche Entomologische Zeitschrift. Hf.1. S.81-99.

Ohaus F. 1914. Beiträge zur Kenntnis der Ruteliden // Stettiner entomologische Zeitung. Bd.75. S.138-156.

Paulian R. 1959. Coléoptères Scarabéides de L'Indochine (Rutélines et Cétonines) (Suite) // Annales de la Société entomologique de France. T.128. P.35-136.

Prokofiev A.M. 2013. [Two new species of the Anomala aulaxgroup from Central Viet Nam (Coleoptera, Scarabaeidae, Rutelinae)] // Euroasian Entomological Journal. Vol.12. No.6. P.553-558 [in Russian].

Zhang B., Lin P. 2008. The Anomala sinica species group from China (Coleoptera: Rutelidae) // Oriental Insects. Vol.42. P.125141.

Zorn C. 2007. Taxonomic revision of the Anomala cuprascensspecies group of Sulawesi and the Papuan region: The species with unidentate protibiae (A. chlorotica subgroup) (Coleoptera: Scarabaeidae: Rutelinae) // Arthropod Systematics and Phylogeny. Vol.65. P.25-71. 